\title{
HACE1 deficiency leads to structural and functional neurodevelopmental defects
}

Vanja Nagy, PhD, Ronja Hollstein, PhD, Tsung-Pin Pai, PhD, Michel K. Herde, PhD, Pisanu Buphamalai, MSc, Paul Moeseneder, MSc, Ewelina Lenartowicz, MSc, Anoop Kavirayani, DVM, Dip. ACVP,

Georg Christoph Korenke, MD, Ivona Kozieradzki, MSc, Roberto Nitsch, PhD, Ana Cicvaric, PhD,

Francisco J. Monje Quiroga, PhD, Matthew A. Deardorff, MD, PhD, Emma C. Bedoukian, MS, Yun Li, PhD,

Gökhan Yigit, PhD, Jörg Menche, PhD, E. Ferda Perçin, MD, PhD, Bernd Wollnik, MD,

Christian Henneberger, MD, Frank J. Kaiser, PhD, and Josef M. Penninger, MD

Neurol Genet 2019;5:e330. doi:10.1212/NXG.0000000000000330

\section{Abstract}

\section{Objective}

We aim to characterize the causality and molecular and functional underpinnings of HACE1 deficiency in a mouse model of a recessive neurodevelopmental syndrome called spastic paraplegia and psychomotor retardation with or without seizures (SPPRS).

\section{Methods}

By exome sequencing, we identified 2 novel homozygous truncating mutations in HACE1 in 3 patients from 2 families, p.Q209* and p.R332*. Furthermore, we performed detailed molecular and phenotypic analyses of Hacel knock-out (KO) mice and SPPRS patient fibroblasts.

\section{Results}

We show that Hace1 KO mice display many clinical features of SPPRS including enlarged ventricles, hypoplastic corpus callosum, as well as locomotion and learning deficiencies. Mechanistically, loss of HACE1 results in altered levels and activity of the small guanosine triphosphate (GTP)ase, RAC1. In addition, HACE1 deficiency results in reduction in synaptic puncta number and long-term potentiation in the hippocampus. Similarly, in SPPRS patient-derived fibroblasts, carrying a disruptive HACE1 mutation resembling loss of HACE1 in $\mathrm{KO}$ mice, we observed marked upregulation of the total and active, GTP-bound, form of $\mathrm{RAC1}$, along with an induction of RAC1-regulated downstream pathways.

\section{Conclusions}

Our results provide a first animal model to dissect this complex human disease syndrome, establishing the first causal proof that a HACE1 deficiency results in decreased synapse number and structural and behavioral neuropathologic features that resemble SPPRS patients.

\author{
Correspondence \\ Dr. Penninger \\ josef.penninger@imba.oeaw.ac.at \\ or Dr. Nagy \\ vanja.nagy@rud.lbg.ac.at
}

\section{RELATED ARTICLE}

\section{Editorial}

HACE1, RAC1, and what else in the pathogenesis of SPPRS?

Page e326

From the IMBA (V.N., T.-P.P., P.M., A.K., I.K., R.N., J.M.P.), Institute of Molecular Biotechnology of the Austrian Academy of Sciences, VBC-Vienna BioCenter Campus, Austria; Department of Medical Genetics (J.M.P.), Life Science Institute, University of British Columbia, Vancouver, Canada; Ludwig Boltzmann Institute for Rare and Undiagnosed Diseases (V.N., E.L.), Vienna, Austria; Section for Functional Genetics at the Institute of Human Genetics (R.H., F.J.K.), University of Lübeck; German Center for Cardiovascular Research (DZHK e.V.) (F.J.K.), Partner Site Hamburg/Kiel/Lübeck, Lübeck; Institute of Cellular Neurosciences (M.K.H., C.H.), University of Bonn Medical School, Germany; Centre for Neuroendocrinology (M.K.H.), Department of Physiology, School of Biomedical Sciences, University of Otago, Dunedin, New Zealand; Department of Neurophysiology and Neuropharmacology (A.C., F.J.M.Q.), Center for Physiology and Pharmacology, Medical University of Vienna, Austria; Drug Safety and Metabolism (R.N.), IMED Biotech Unit, AstraZeneca, Gothenburg, Sweden; Division of Genetics and the Roberts Individualized Medical Genetics Center (M.A.D., E.C.B.), Children's Hospital of Philadelphia, PA; Departments of Pediatrics (M.A.D.), University of Pennsylvania Perelman School of Medicine, Philadelphia, PA; Institute of Human Genetics (Y.L., G.Y., B.W.), University Medical Center Göttingen, Germany; Institute of Neurology (C.H.), University College London, UK; German Center for Neurodegenerative Diseases (DZNE) (C.H.), Bonn, Germany; Zentrum für Kinder- und Jugendmedizin (G.C.K.), Neuropädiatrie, Klinikum Oldenburg, Germany; Department of Medical Genetics (E.F.P.), Faculty of Medicine, Gazi University, Ankara, Turkey; CeMM Research Center for Molecular Medicine of the Austrian Academy of Sciences (P.B., J.M.), Vienna, Austria.

Funding information and disclosures are provided at the end of the article. Full disclosure form information provided by the authors is available with the full text of this article at Neurology.org/NG. 


\section{Glossary}

ANOVA = analysis of variance; HACE1 = HECT Domain And Ankyrin Repeat Containing E3 Ubiquitin Protein Ligase 1; $\mathbf{H D}=$ healthy donor; KO = knock out; $\mathbf{L T P}=$ long-term potentiation; $\mathbf{N A D P H}=$ nicotinamide adenine dinucleotide phosphate oxidase; $\mathbf{O F T}$ = open-field test; $\mathbf{P P I}=$ pre-pulse inhibition; $\mathbf{R A C 1}$ = Ras-related C3 botulinum toxin substrate 1 ; $\mathbf{R O S}=$ reactive oxygen species; SPPRS = spastic paraplegia and psychomotor retardation with or without seizures; WT = wild type.

Homologous to the E6-AP carboxyl terminus domain and ankyrin repeat containing E3 ubiquitin-protein ligase 1 (HACE1), was identified to be downregulated in a number of tumors, as well as to play a role in inflammatory responses. ${ }^{1-4}$ Analysis of Hace1 knock-out (KO) mice showed HACE1 is ubiquitously expressed, with relatively high expression in the brain. ${ }^{2}$

A neurodevelopmental disorder named spastic paraplegia and psychomotor retardation with or without seizures (SPPRS) has recently been described in 15 patients of 6 unrelated families, associated with mutations throughout the HACE1 gene. ${ }^{5-7}$ Mutations are predicted to be deleterious to HACE1 protein function, either disrupting folding or causing a frame shift and early termination of translation, resulting in no detectable protein product in patient-derived fibroblasts. ${ }^{6,7}$ Clinical manifestations are variable and include early-onset developmental delays, severe intellectual disability, epilepsy, hypotonia, spasticity, ataxia, and difficulty with verbal communication. MRI findings include enlarged ventricles, hypoplastic corpus callosum, and altered white and gray brain matter ratios. There are several known targets for HACE1 ubiquitination, including Ras-related $\mathrm{C} 3$ botulinum toxin substrate 1 (RAC1), small GTPase, important for different aspects of brain development and neuronal function. ${ }^{4,8-11}$ In addition to cytoskeletal remodeling, RAC1 can regulate reactive oxygen species (ROS) levels as part of the nicotinamide adenine dinucleotide phosphate oxidase (NADPH) complex. ${ }^{12}$ Correspondingly, Hace1 KO mice were reported to have elevated ROS levels. ${ }^{13}$ While the role for hace1 was recently described in embryonic development in Xenopus laevis $^{14}$ and murine HACE1 has been implicated in Huntington disease, ${ }^{13}$ nothing is known about the role of HACE1 during mammalian nervous system development or the molecular underpinnings of SPPRS. To elucidate the neurodevelopmental pathophysiology of SPPRS, we therefore performed detailed analysis of Hacel $\mathrm{KO}$ mice and confirmed our findings in SPPRS patient-derived fibroblasts.

\section{Methods}

See supplemental information (e-methods, links.lww.com/ NXG/A151) for more details.

\section{Standard protocol approvals, registrations, and patient consents}

Genetic and clinical data of patients $6-8$ were published. ${ }^{6}$ Our newly identified patients are labeled as patients 9-11. Genetic data regarding patient 9 were produced as part of a clinical diagnostic service (GeneDx), and the research study including patients 10 and 11 has been approved by the ethics committee at The University of Göttingen. Biological materials of patients and healthy donors (HDs) and written informed consents were obtained in accordance with the Declaration of Helsinki. Fibroblasts from 2 female patients and 1 male patient only, 6, 7, and 10, respectively, are used in this study, as no consent was available for the others.

\section{Mice}

Animals were housed at the Institute of Molecular Biotechnology, Vienna, Austria, maintained under a 12-hour light/dark cycle, and provided with food and water ad libitum. Experiments described in this study were approved by the Bundesministerium fur Wissenschaft, Forschung und Wirtschaft (BMWFW-66.015/0004-WF/V/3b/2015) and performed according to EU-directive 2010/63/EU.

\section{Immunoblotting}

The following antibodies were used for standard Western blotting protocols: anti-HACE1 at 1:1,000 dilution (AbCam), anti-Cyclin D1 at 1:1,000 (AbCam), anti-Glyceraldehyde-3Phosphate Dehydrogenase at 1:1,000 dilution (Cell signalling), anti-RAC1 at 1:1,000 dilution (Millipore), anti-B-actin at 1:5,000 dilution (Sigma, clone AC-74), and appropriate secondary horseradish peroxidase-linked whole antibodies (GE Healthcare).

\section{Histology}

Selected brains were isolated, processed, embedded, sectioned, and stained by the Histopathology Facility at the Vienna Biocenter Core Facilities (VBCF), member of the Vienna Biocenter (VBC), Austria. Briefly, 2- $\mu \mathrm{m}$-thick coronal or sagittal paraffin-embedded sections were prepared by routine microtomy and stained with hematoxylin and eosin (H\&E, Shandon* Harris Hematoxylin Acidified; Thermo Scientific Shandon Eosin Y; Fisher Scientific), Luxol Fast Blue-Cresyl Violet (LFBCV, Sigma), or with anti-Myelin Basic Protein antibody (Abcam, 1:100). Slides were imaged using a Zeiss Axioskop 2 MOT microscope (Carl Zeiss Microscopy) and subsequently digitized with the Pannoramic FLASH $250 \mathrm{II}$ automated slide scanner (3D Histech). Images were acquired with the Pannoramic Viewer software (3D Histech) and with SPOT Insight camera (Diagnostic Instruments, Inc.).

\section{MRI}

Anesthetized male C57Bl6/J mice 8-10 weeks of age and their Hace1 KO littermates were imaged in the Preclinical Imaging Facility at VBCF (pcPHENO, VBCF), member of the VBC, Austria, using a 15.2 T MRI (Bruker BioSpec, 
Ettlingen, Germany). Values were normalized to brain size, averaged, and presented as percentage of total brain volume, and unpaired Student's $t$ test was used to determine statistical significance.

\section{Behavioral testing}

Open-field test (OFT) and elevated plus maze were performed as described previously using an automated activity system (TSE-Systems, Germany). ${ }^{15}$ Unpaired Student's $t$ test was used to determine significance. Accelerating rotarod was performed on a 5-40 rpm accelerating apparatus (Ugo Basile), as described previously. ${ }^{16}$ Significance was determined by 2 -way analysis of variance (ANOVA) with Sidak's multiple comparisons. In the ladder rung walking task (pcPHENO, VBCF), mice were trained to walk across a ladder (length: $80 \mathrm{~cm}$; spacing of rungs: $1 \mathrm{~cm}$ ) toward an escape ladder in the TSE MotoRater system (tsesystems.com). Mice were recorded and manually scored using SimiMotion software 8.5.0.327. ${ }^{17}$ Unpaired Student's $t$ test was used to determine significance. T-maze was performed as described previously. ${ }^{18}$ Significance of deviation of the number of successes in mutant vs wild-type (WT) mice was evaluated using a binomial test. For acoustic fear conditioning (pcPHENO, $\mathrm{VBCF})$, mice were trained to associate the conditioned sound stimulus ( $\mathrm{CS}=85 \mathrm{~dB}, 10 \mathrm{kHz}$ ) with the unconditioned foot shock stimulus delivered by the floor grid (US $=1.5 \mathrm{~mA}$ ), as described previously, using Coulbourn Habitest operant cages (Coulbourn Instruments, MA and FreezeFrame, Actimetrics, IL). ${ }^{19}$ Unpaired Student's $t$ test was used to determine significance. Mice were trained in the Morris water maze (pcPHENO, VBCF) as described previously. ${ }^{20}$ Unpaired Student's $t$ test was used to analyze the short- and long-term memory data and 2-way ANOVA with Sidak's multiple comparison test for the latency to reach the platform. Mice were tested for startle responses and prepulse inhibition (PPI) as described previously ${ }^{21}$ using the SRLAB Startle Response System (San Diego Instruments) chamber. Two-way ANOVA with Sidak's multiple comparison test was used to determine significance.

\section{Hippocampal slices preparation and electrophysiologic recordings}

Electrophysiologic field recordings in the stratum radiatum of acute hippocampal slices were performed as described previously. ${ }^{22}$ Two-population Student's $t$ test were used to determine significance.

\section{Synaptic number analysis}

Hace1 KO; Thyl-green fluorescent protein (GFP) line $\mathrm{M}$ and hace1 WT; and Thyl-GFP line $\mathrm{M}^{16}$ were analyzed using the LSM700 Axio Imager. Synapse number counts and measurement of neurite lengths were performed using Image J. ${ }^{23}$ Statistical analysis was performed using Student's $t$ test.

\section{Active RAC1 pulldown}

Cellular levels of active RAC1 in fibroblasts were analyzed using the Active Rac1 Pull-Down and Detection Kit (Thermo Fisher Scientific) according to the manufacturer's instructions.

\section{Migration assay}

Primary dermal fibroblasts from patients 6, 7, and 10 and HDs were seeded at high density in 24-well plates for 24 hours and scratched using a pipette tip. The area of the scratch at 0 and 24 hours following the scratch was measured digitally in pixels, and the relative gap closure was calculated and normalized to wild-type cells. Unpaired Student's $t$ test was used to determine significance.

\section{ROS detection in the mouse brain and human primary dermal fibroblasts}

Twenty-micrometer coronal mouse brain sections were washed $2 \mathrm{X}$ in phosphate buffered saline and incubated in 10-mM dihydroethidium for 15 minutes at $37^{\circ} \mathrm{C}$. Sections were washed twice in phosphate buffered saline and imaged with a Zeiss Axioplan2 microscope. Levels of ROS in fibroblasts were investigated using CellROX Deep Red staining (Thermo Fischer) followed by flow cytometric analysis according to the manufacturer's instructions. Statistical analysis was determined using unpaired Student's $t$ test.

\section{Results}

\section{Identification of novel HACE1 mutations in SPPRS patients}

Family 1 originating from Saudi Arabia had 1 affected female individual, patient 9 , born to healthy, consanguineous parents (figure e-1A, links.lww.com/NXG/A148). The patient presented with similar clinical symptoms as previously reported cases of SPPRS, including severe intellectual disability, developmental delay, and inability to sit or speak by the age of 5 years. ${ }^{6}$ Cranial MRI revealed microcephaly and brachycephaly, as well as hypoplastic corpus callosum and likely brainstem abnormality, small sella with ectopic neurohypophysis, and mild ventriculomegaly (figure e-1B). Additional clinical findings include mild facial dysmorphia, skeletal abnormalities, and ulnar deviation of the wrists and small feet (figure e-1C). In an unrelated consanguineous family 2 originating from Turkey, born to a healthy father and mother with Hashimoto disease are one female (patient 10) and one male (patient 11), 4 and 6 months of age at initial admission (Figure e-1D). During pregnancy, the mother was euthyroid and both children were carried to term. Patients had variable clinical symptoms in comparison with patient 9 and those previously reported, including hypotonia, small feet, enlarged head circumference, inverted and wide spaced nipples, facial dysmorphic features, and strabismus (figures e-1, E and F). Considering the pronounced hypotonia in all 3 patients, ataxia was difficult to determine. For detailed clinical symptoms of all patients, please refer to table.

In these 3 patients, mutations in $H A C E 1$ were identified by exome sequencing and verified by Sanger sequencing: patient 9 carries a homozygous c.625C>T; p.Q209* HACE1 mutation in exon 8, NM_020771.3:c.625C>T, p.Q209* (chr6:104 797018 on the hg 38 build); patients 10 and 11 carry a homozygous c.994C>T; p.R332* HACE1 mutation in exon 11, NM_020771.3:c.994C>T, p.R332* (chr6:104 791 584) 
Table Comparison of clinical characteristics and genetic findings in reported patients

\begin{tabular}{|c|c|c|c|c|c|c|}
\hline & & Patient 6 & Patient 7 & Patient 9 & Patient 10 & Patient 11 \\
\hline \multirow[t]{7}{*}{ Background } & HACE1 mutation & & $\begin{array}{l}\text { Nonsense; } c .2242 C>T ; \\
\text { p.R748* and Frameshift; }\end{array}$ & Nonsense; c.625C > T; p.Q209X & Nonsense; c.994C > T; p.R332X & Nonsense; c.994C > T; p.R332X \\
\hline & & $\begin{array}{l}\text { c.2019- } \\
\text { 2020instTTAGGTATTTTAAGGT; }\end{array}$ & $\begin{array}{l}\text { c.2019- } \\
\text { 2020insTTAGGTATTITAG }\end{array}$ & Saudi Arabia & Turkey & Turkey \\
\hline & & $\begin{array}{l}\text { ATr; p.P674Ffs*5 (Hollstein } \\
\text { et al. }{ }^{6} \text { ) }\end{array}$ & $\begin{array}{l}\text { GTATT; } p . P 674 F f s * 5 \\
\text { (Hollstein et al. }^{6} \text { ) }\end{array}$ & Family 1 & Family 2 & Family 2 \\
\hline & Sex & $\mathrm{F}$ & M & $\mathrm{F}$ & $\mathrm{F}$ & M \\
\hline & Birth weight (kg) & 3.37 & 3.4 & 3.0 & 4.140 (97th percentile) & 3.480 \\
\hline & Birth OFC (cm) & 33 & 34 & UK & $37 \mathrm{~cm}$ ( $97^{\text {th }}$ percentile) & UK \\
\hline & Gestational age & 39 & 40 & 40 & 40 & 40 \\
\hline \multirow[t]{5}{*}{ Development } & Recent growth parameters & & & & & \\
\hline & Age & 10 y $11 \mathrm{mo}$ & 7 y 8 mo & 5 y 4 mo & $4 \mathrm{mo}$ & $6 \mathrm{mo}$ \\
\hline & Height $(\mathrm{cm})$ & BMI 24.8 & BMI 21.17 & $86.5, Z=-5.67$ (scoliosis) & 67 (>97th percentile) & 66 (75th percentile) \\
\hline & Weight (kg) & & & $15.5, z=-1.6$ & 9.5 (>97th percentile) & 9.7 (>97th percentile) \\
\hline & OFC (cm) & 54 (+0.5 SD) & $53(+0.2$ SD) & $4 y, 44, z=-3.72$ & 44 (>97th percentile) & 43.5 (75th percentile) \\
\hline \multirow[t]{9}{*}{ Neurology } & Sitting and walking & $4 y$ & $3-4 y$ & Not at $5 \mathrm{y}$ & Not at $4 \mathrm{mo}$ & Not at 6 mo \\
\hline & Language & Inarticulate speech & Inarticulate speech & None at $5 \mathrm{y}$ & Too young to be evaluated & Too young to be evaluated \\
\hline & General & Developmental delay & Developmental delay & Developmental delay & Developmental delay & Developmental Delay \\
\hline & Epilepsy & None & $\begin{array}{l}\text { Myoclonic seizures and } \\
\text { focal epilepsy }\end{array}$ & None & None & None \\
\hline & Stereotypies & None & None & Bruxism & None & None \\
\hline & Mobility & $\begin{array}{l}\text { Hypotonia and unstable ataxic } \\
\text { gait }\end{array}$ & $\begin{array}{l}\text { Hypotonia and unstable } \\
\text { ataxic gait }\end{array}$ & Hypotonia & Hypotonia & Hypotonia \\
\hline & Ophthalmic findings & None & None & Retinal dystrophy & Strabismus of the right eye & Bilateral strabismus \\
\hline & Hearing & No abnormality & No abnormality & $\begin{array}{l}\text { Bilateral sensorineural loss noted } \\
\text { at } 4 \mathrm{y}\end{array}$ & No abnormality & No abnormality \\
\hline & Intellectual disability & Yes & Yes & Yes & Too young to be evaluated & Too young to be evaluated \\
\hline Neuroradiology & MRI & Hypoplastic corpus callosum & $\begin{array}{l}\text { Hypoplastic corpus } \\
\text { callosum }\end{array}$ & $\begin{array}{l}\text { Microcephaly and brachycephaly; } \\
\text { hypoplastic corpus callosum and } \\
\text { likely brainstem abnormality; } \\
\text { small sella with ectopic } \\
\text { neurohypophysis; mild } \\
\text { ventriculomegaly }\end{array}$ & Normal & Normal \\
\hline
\end{tabular}


(figure 1A). Both are nonsense mutations predicted to result in a truncated HACE1 protein product with no catalytic activity. Parents in both families were determined to be heterozygous carriers. Figure 1A also indicates all previously reported HACE1 mutations in SPPRS patients. ${ }^{5,6}$ Thus, we have identified three new cases with biallelic HACE1 mutations associated with marked and diverse neurologic as well as non-neurologic abnormalities, diagnosed to be SPPRS.

\section{Hace1-mutant mice exhibit brain morphologies similar to SPPRS patients}

To determine whether Hace1 KO mice develop any clinical symptoms of SPPRS patients, we first analyzed structural and cellular features of mutant mouse brains using 15.2 T MRI and/or histologic staining at different developmental stages. Histologic examination of mouse brains at embryonic day (E) 18.5, postnatal day (P) 0.5 , and P14.5 revealed no evident defects cortical lamination, cerebellar foliation, hippocampal architecture, or cellular aberration and density in any developmental period examined (figure 1, B-D). However, enlarged ventricles and hypoplastic corpus callosum (figure 1, $\mathrm{B}$ and $\mathrm{C}$ ) were noted in Hace1 $\mathrm{KO}$ animals as compared with WT littermates, as early as E18.5 and P0.5, respectively.

Western blot analyses of 8-week-old mouse brain lysates revealed HACE1 to be expressed throughout the adult mouse brain, which was absent in the brains of Hacel $\mathrm{KO}$ mice (figure 2A). Total volume and morphology of the Hace1 KO adult mouse brain as compared with WT littermates measured by MRI and/or histologic examination revealed no whole-brain volumetric or cellularity differences as compared with WT littermates (figure 2, B and C). Review of histologic sections also revealed no abnormality in cortical laminar organization and cellular density in the adult brain (figure 2D). Detailed analysis of different brain regions via MRI also showed no significant differences in the volumes of the cortex, colliculi, thalamus, and putamen, comparing adult WT and Hace1 KO brains, with a small decrease in the volume of the olfactory bulb (data not shown). The adult cerebellar volume and foliation as well as cortical laminar organization were comparable between Hacel KOs and their control WT littermates (figure 2, E and F). Hippocampal volume was significantly decreased as measured by MRI (figure 2G); however, there were no evident aberrations in cellularity and architecture on microscopic examination of hippocampi in adult animals (figure $2 \mathrm{H}$ ).

Of interest, volumetric MRI reconstructions revealed a significant reduction in whole-brain white matter (figure e-2, A-D, links.lww.com/NXG/A149) in Hace1 KO adult mice as compared with their WT littermates, substantiated by myelin basic protein staining and volumetric MRI analysis (figure e-2, B-D), similar to findings in reported SPPRS patients ${ }^{5-7}$ and patient 9 described here (figure $1 \mathrm{C}$ and table). Also, noted was a reduction of the anterior commissure in $\mathrm{Hacel} \mathrm{KO}$ mice as compared with WT littermates (figure e-2C). In addition, in line with findings in SPPRS patients, as well as adult and 


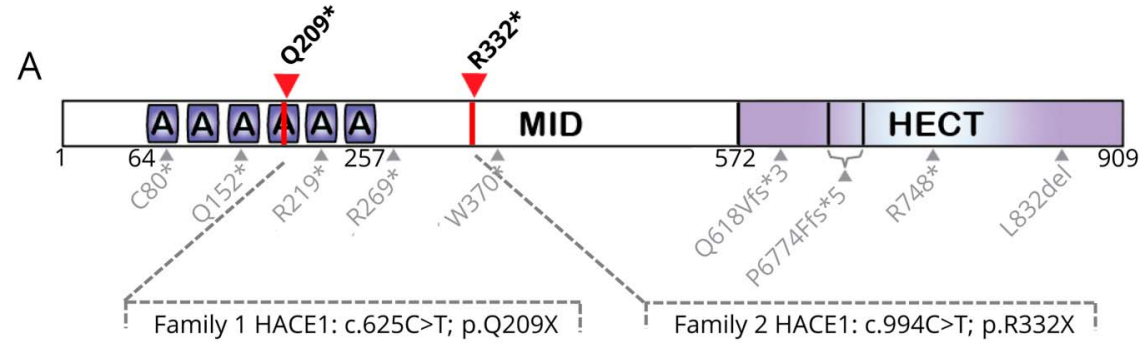

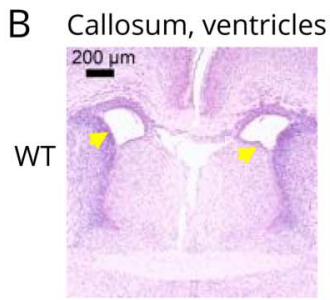

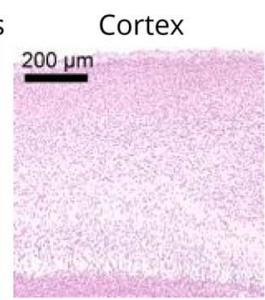

Hippocampus
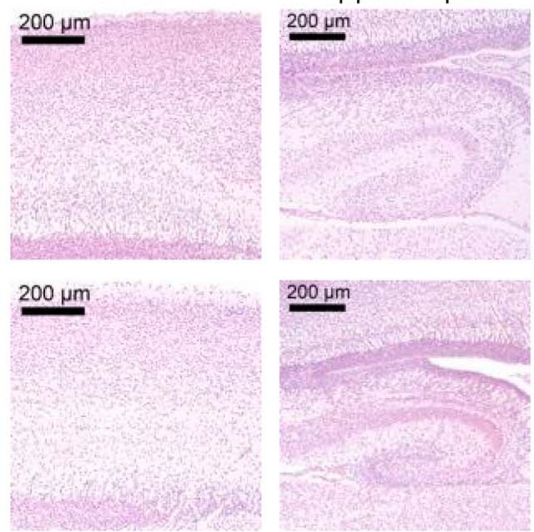

C

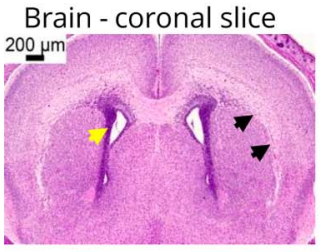

WT
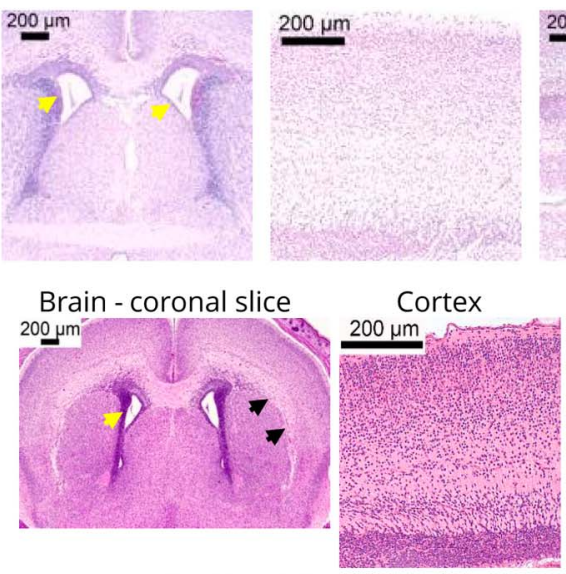

Hippocampus
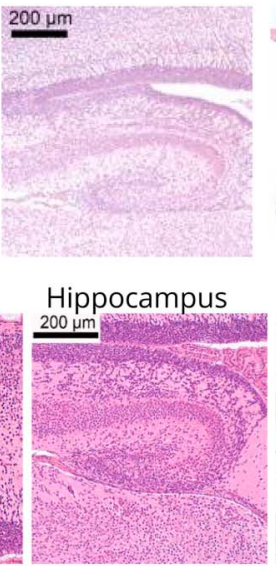

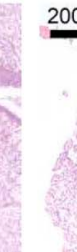
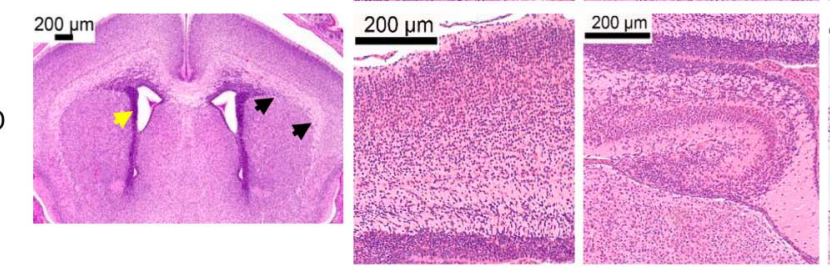

D

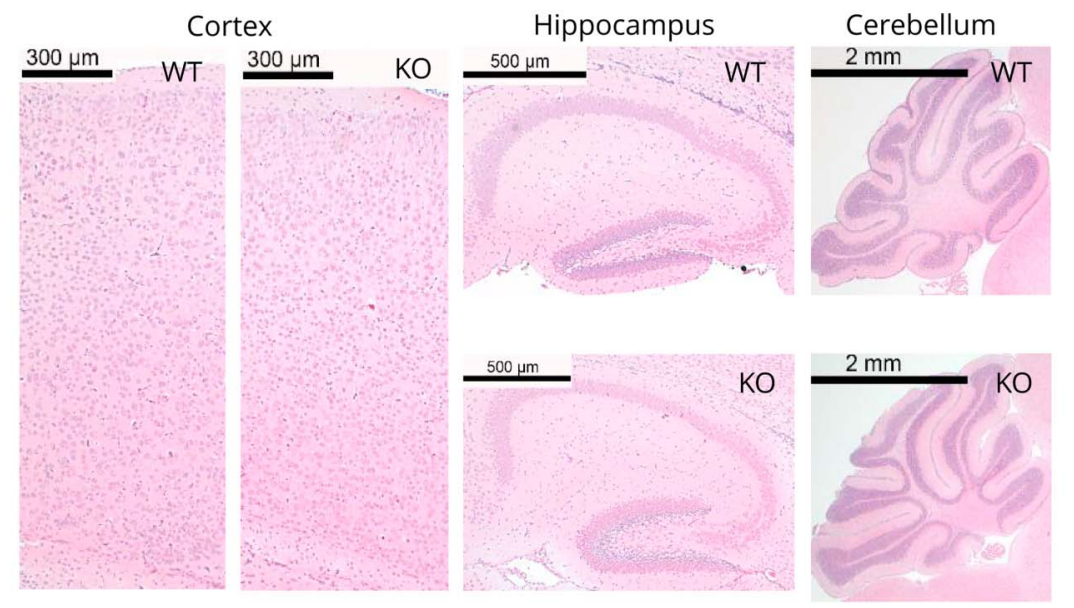

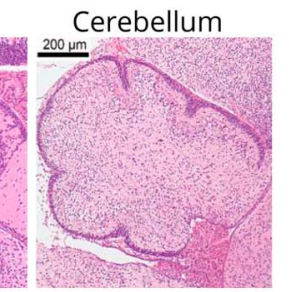

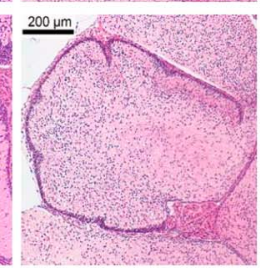

Cerebellum
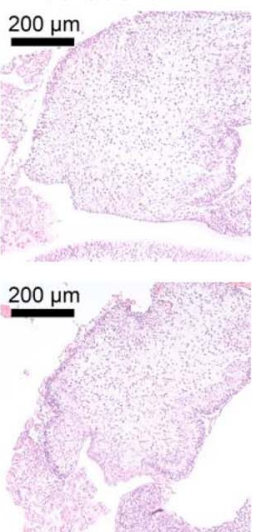

Cerebellum

$\mathrm{KO}$
(A) Schematic representation of HACE1 protein and locations of mutations of previously published (in gray) and novel mutations reported here (red arrows, black letters). (B) H\&E-stained sections of wild-type (WT) and Hace 1 KO mice at E18.5 reveal no major structural abnormality across the regions studied, with slight ventriculomegaly in the Hace $1 \mathrm{KO}$ brain as compared with controls, left panel (yellow arrows). (C) H\&Estained coronal sections of the newborn brain of WT and Hace $1 \mathrm{KO}$ mice at PO.5 reveal ventricular dilation in the Hace $1 \mathrm{KO}$ brain (yellow arrows) and attenuation of the corpus callosum (black arrows). (D) H\&E-stained sections of WT and Hace1 KO mice at P14.5. Cortical lamination, hippocampal formation, and the cerebellar vermis are comparable between WT and Hace $1 \mathrm{KO}$ in all 3 age groups studied. All brain regions are labeled in the figure and magnifications are as indicated. $\mathrm{A}=$ ankyrin domain: $\mathrm{H} \& \mathrm{E}=$ hematoxylin and eosin; HECT = homologous to the E6-AP carboxyl terminus; MID = middle region. 
A
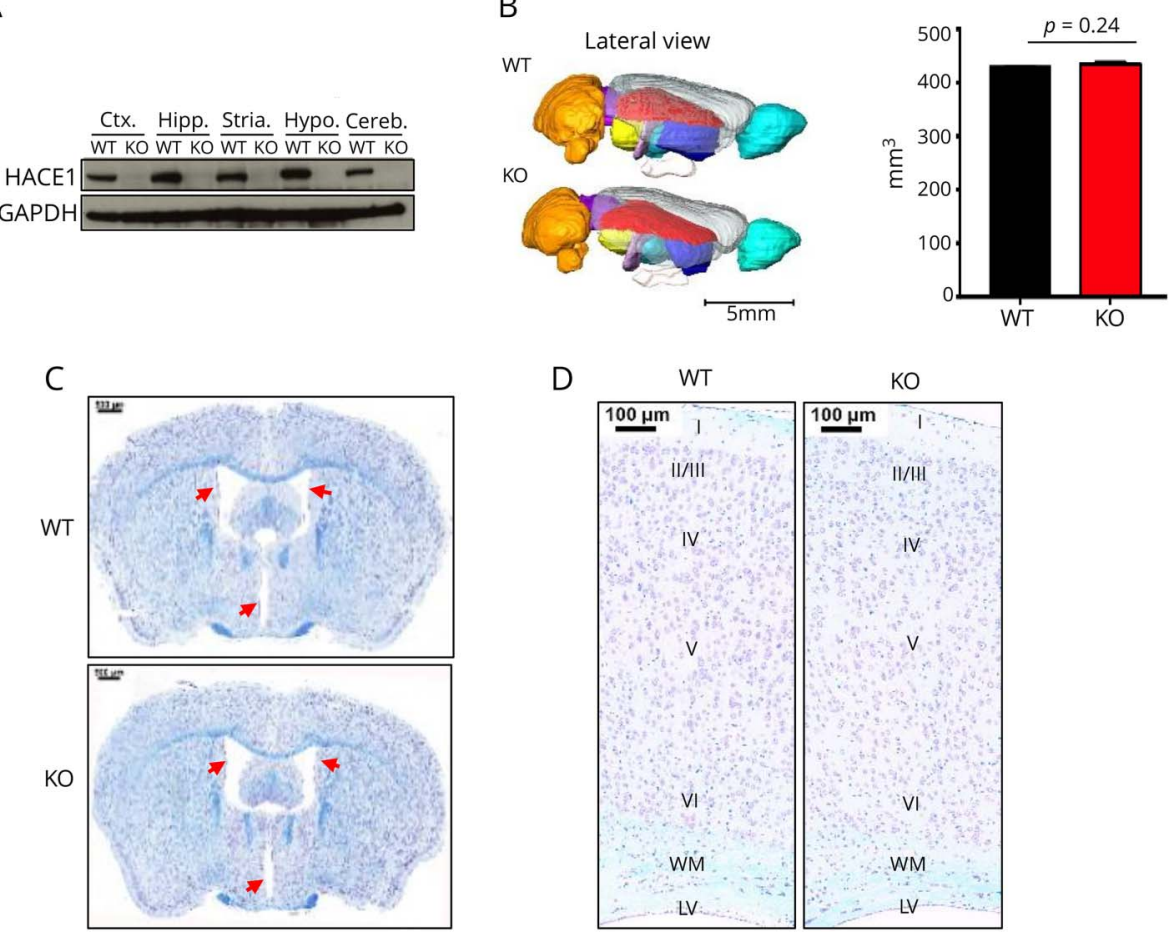

D

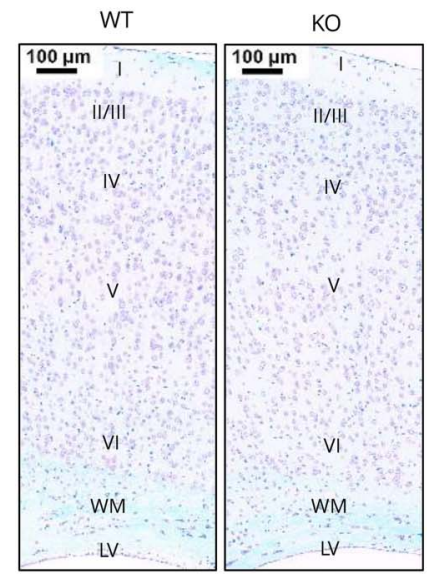

E. Cerebellum
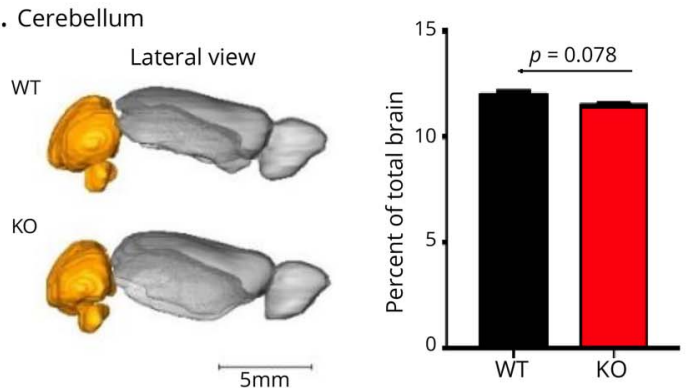

$\mathrm{F}$

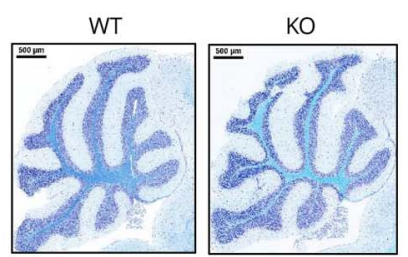

$\mathrm{H}$

G. Hippocampus

WT

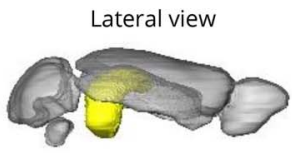

KO

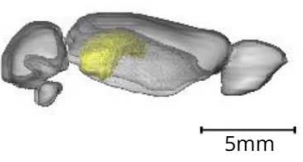

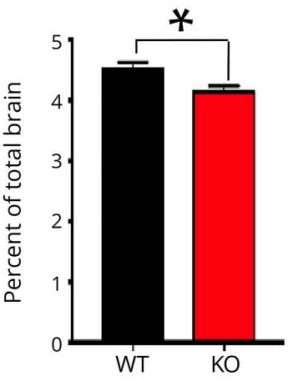

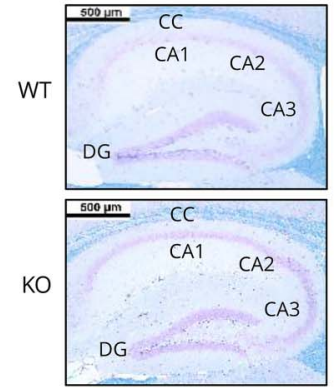

(A) Western blot analysis depicting HACE abundance in the indicated 8-12-week-old male mouse brain regions of wild-type (WT) and Hace1 knock-out (KO) mice. (B) Pseudocolored 3D reconstruction of lateral MR images of representative whole mouse brains, and quantification (mean values \pm SEM) showing no difference in total brain volumes in 8-12-week-old male WT and Hace1 KO littermates. Orangecerebellum, yellow-hippocampus, redcorpus callosum, light blue-thalamus, purple-colliculi, turquoise-olfactory bulbs, and dark blue-putamen; WT $n=12$ and $K O n=9 ; p$ value as indicated in the bar graph; unpaired Student's $t$ test. (C) LFBCV-stained coronal sections of whole WT and Hace1 KO adult mouse brains. Ventriculomegaly (red arrows) is evident in the KO brain as compared with the WT littermate. (D) LFB-CV-stained coronal sections of the adult cortex show no defects in cellularity or lamination (laminae I to $\mathrm{VI}$ ) in Hace1 KO mice. (E) Pseudocolored (orange) 3D reconstructed MRI images of representative lateral views of WT and Hace $1 \mathrm{KO}$ littermate cerebelli showing no significant volumetric differences in Hace1 KO vs WT control littermates. Right, quantification of volumetric differences; mean values \pm SEM; WT $\mathrm{n}=12 ; \mathrm{KO} \mathrm{n}=9 ; p$ value as indicated in the figure; unpaired Student's $t$ test. (F) Selected LFB-CV-stained sagittal sections of the cerebellum showing no apparent differences between WT and Hace1 KO brains. (G) Pseudocolored (yellow) 3D reconstruction of MRI images of representative lateral view of hippocampi of WT and Hace1 KO mice shows a significant reduction in hippocampal volume in Hace 1 KO brains; quantification is shown in the right panel; mean values \pm SEM; WT $n=12$ and KO $n=9 ;{ }^{*} p \leq 0.05$; unpaired Student's $t$ test. (H) LFB-CV-stained coronal sections of the hippocampus show no notable morphological difference in cellularity between WT and Hace 1 KO brains. Scale bars as labeled in the images. $\mathrm{CA}=$ cornu ammonis; $\mathrm{CC}=$ corpus callosum; cereb = cerebellum; $\mathrm{Ctx}=$ cortex; $\mathrm{DG}=$ dentate gyrus; hipp $=$ hippocampus; hypo = hypothalamus; LFB$\mathrm{CV}=$ luxol fast blue - cresyl violet; $\mathrm{LV}=$ lateral ventricle; stria = striatum; $\mathrm{WM}=$ white matter. developing mouse brains, we observed enlarged ventricles in Hacel $\mathrm{KO}$ mice as compared with control littermates (figure 2C). These data show that Hace1 KO mice phenocopy key structural features associated with SPPRS patients.

\section{HACE1-deficient mice exhibit locomotion and associative learning disabilities}

To assess what, if any, behavioral defects can be detected in Hace1 $\mathrm{KO}$ mice, we subjected cohorts to an extensive battery of behavioral assays. The most notable clinical features of SPPRS are intellectual disability and ataxia ${ }^{5-7}$; we therefore focused on hippocampal- and cerebellar-dependent tasks, principal brain regions regulating those behaviors in mice. Hace1 $\mathrm{KO}$ mice generated in our group previously are generally healthy, viable, and fertile. ${ }^{2}$ First, we found no significant differences in anxiety levels in Hace1 WT and KO littermates analyzed by the OFT and the elevated plus maze (figure e-3, A and B, links.lww.com/NXG/A150); however, 
we noted a reduction in the distance traveled during the testing (figure 3A). These data indicated that while our mice exhibited normal anxiety levels, there may be a locomotion defect. Therefore, we tested Hacel KO mice for any locomotion and gait defects. WT and Hacel $\mathrm{KO}$ mice were tested in the accelerating rotarod task, a standard assay to determine locomotion and gait defects. ${ }^{16}$ While Hace $1 \mathrm{KO}$ mice and control littermates had similar latencies to fall off the rotating rod in the first trial, Hace $1 \mathrm{KO}$ mice exhibited shorter latencies to fall on all subsequent trials (figure 3B). We further analyzed the mice on a ladder rung walking task, which enables the observer to analyze coordinated front and hind paw placement on each individual rung of the ladder. ${ }^{17}$ While Hace1 $\mathrm{KO}$ animals were capable of performing the task without falling off the apparatus and showed similar percentages of correct placement over all limbs analyzed, percent of major

Figure 3 Behavioral analysis of Hace1 $\mathrm{KO}$ mice reveals deficits in specific locomotion, learning, and memory tasks

A Open-Field Test

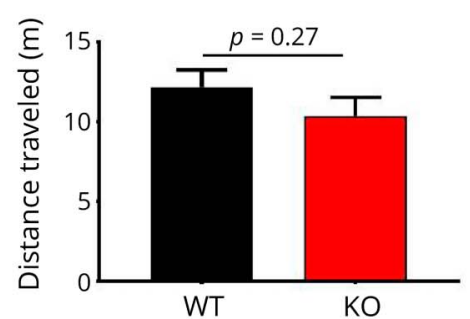

WT

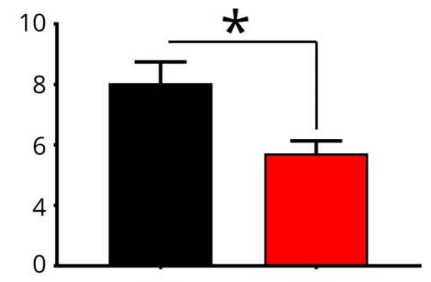

WT

Elevated Plus Maze

$\mathrm{KO}$
B. Accelerating Rotarod

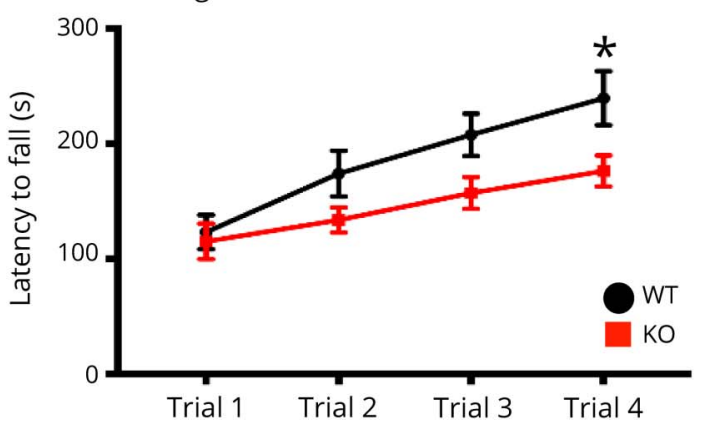

C. Ladder Rung Walking Task

Score 0-2

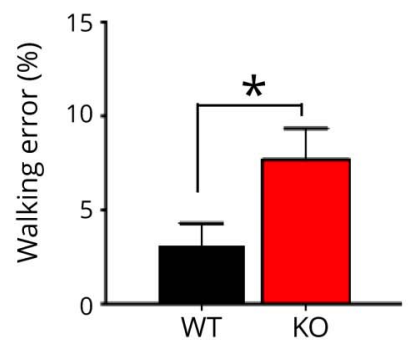

D. Acoustic fear conditioning

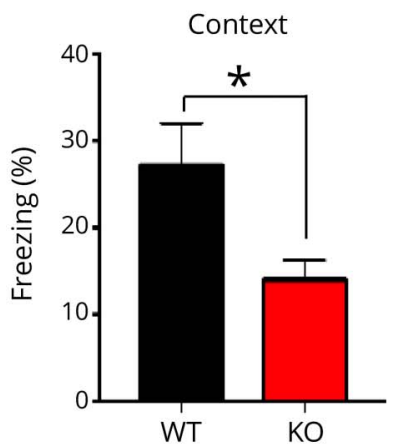

Score 3-4
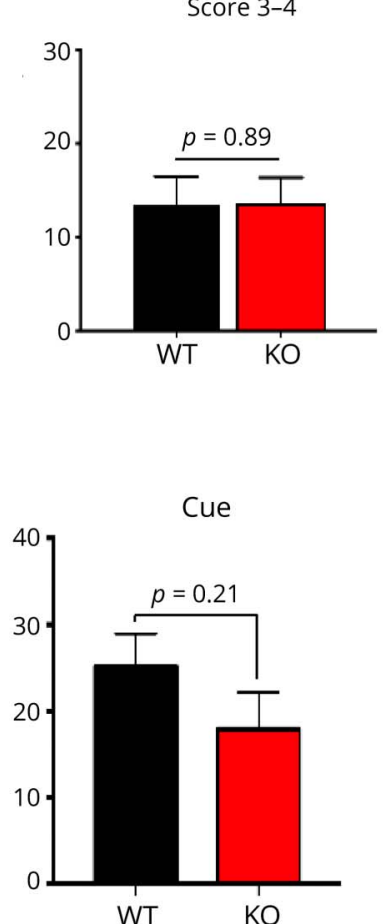
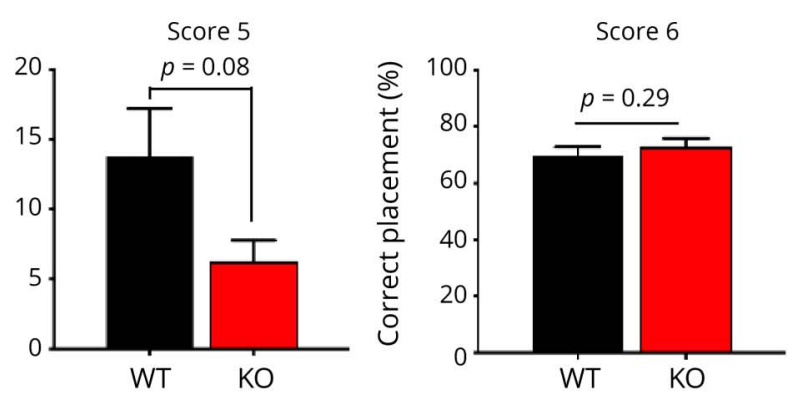

\section{E. Acoustic startle}

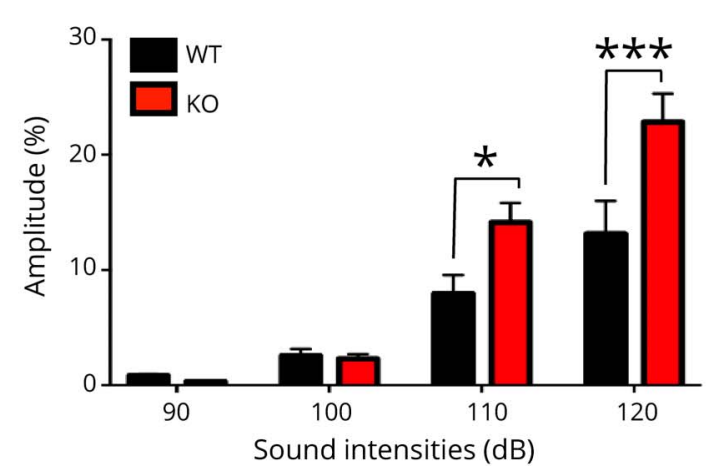

(A) Open-field maze (OFM) and elevated plus maze (EPM) showed slight and significant reductions in the distances Hace1 KO mice had traveled as compared with their WT littermates, respectively; data are shown as mean values \pm SEM; WT $n=10$ and KO $n=10$; * $p \leq 0.05$ or as indicated in the bar graphs; unpaired Student's $t$ test. (B) Hace $1 \mathrm{KO}$ mice show significantly shorter latencies to fall off the accelerating rotarod; mean values $\pm \mathrm{SEM}$; $\mathrm{WT} \mathrm{n}=19$ and $\mathrm{KO} \mathrm{n}=21 ;{ }^{*} p \leq$ 0.05; 2-way ANOVA with Sidak's multiple comparison test. (C) Ladder rung walking task illustrates a significant increase in the percentage of total misses, deep slips, and/or slight slips (0-2 score) in Hace1 KO mice compared with WT littermate controls; mean values \pm SEM; WT $n=12$ and KO $n=9$; * $p \leq 0.05$; unpaired Student's $t$ test. No significant differences were noted in the 3-4 score (replacement and correction), 5 score (partial placement), or 6 score (correct placement). Bar graphs depict mean values of all paws \pm SEM; $p$ values are indicated in figures; WT $n=12$ and KO $n=9 ;$ unpaired Student's $t$ test. (D) Significant deficiency in long-term contextual memory as measured by auditory fear conditioning was detected in Hace $1 \mathrm{KO}$ mice as compared with WT littermates (left panel); mean values \pm SEM; WT $n=16$ and KO $n=13 ;{ }^{\star} p \leq 0.05$; unpaired Student's $t$ test. Cued fear conditioning was not significantly different in Hace $1 \mathrm{KO}$ mice as compared with WT littermates; mean values \pm SEM; WT $n=16 ; \mathrm{KO} n=13 ; p$ value $=0.21$; unpaired Student's $t$ test. (E) Hace $1 \mathrm{KO}$ s show significant reduction in acoustic startle inhibition at 110 and $120 \mathrm{~dB}$ as compared with WT littermates. Mean values $\pm \mathrm{SEM}$; WT $n=14 ; \mathrm{KO} n=11$; * $p \leq 0.05 ;$ *** $p \leq 0.001 ; 2-\mathrm{way}$ ANOVA with Sidak's multiple comparison test. ANOVA = analysis of variance; $\mathrm{KO}=$ knock out; $\mathrm{WT}=$ wild type. 
missteps made were significantly higher as compared with WT littermates. Both groups of animals had similar placement and correction scores, while WT animals had a higher percentage of partial placement on rungs (figure 3C). Thus, Hace1 $\mathrm{KO}$ mice exhibit locomotion and gait deficits.

The second notable clinical feature of SPPRS patients is intellectual disability (table) ${ }^{5-7}$ To determine whether learning and memory processes are altered in Hacel $\mathrm{KO}$ animals, we analyzed mutant mice in various hippocampal-dependent behavioral tasks. In the Morris water maze, $\mathrm{KO}$ mice were able to swim normally and there were no apparent differences in latencies between WT and Hacel $\mathrm{KO}$ littermates to find the visible platform (not shown), in escape latencies during any of the training days (figure e-3C, links.lww.com/NXG/A150), nor in short- or long-term memory (figure e-3C, right panels). Likewise, there were no differences in T-maze between WT and Hace1 $\mathrm{KO}$ animals (figure e-3D). However, subjecting the animals to cued and contextual fear conditioning revealed significantly reduced freezing responses in the contextual aspect of the task in Hacel KO mice compared with WT littermates (figure 3D).

In addition, Hacel $\mathrm{KO}$ mice exhibited significantly enhanced startle amplitude responses or reduced startle inhibition, in the acoustic startle task at presentation of $110-$ and $120-\mathrm{dB}$ startle sounds as compared with their WT littermates (figure $3 \mathrm{E})$. These results also suggest $\mathrm{Hace} 1 \mathrm{KO}$ animals do not have any hearing deficiencies. PPI was reduced for all prepulse intensities presented $(80,85,90$, and $95 \mathrm{~dB})$; however, this reduction was not significant when comparing Hacel $\mathrm{KO}$ animals with WT controls (figure e-3E, links.lww.com/NXG/ A150). These data indicate that, besides locomotion defects, associative learning is altered in Hace1 $\mathrm{KO}$ mice, paralleling behavioral findings in human SPPRS patients.

\section{Hace1 deficiency results in altered hippocampal synaptic transmission and reduced synapse numbers}

We and others have previously shown that altered synaptic transmission and plasticity at CA3-CA1 Schaffer collaterals can underlie deficits of contextual fear memory. ${ }^{22,24}$ We tested whether synaptic transmission and plasticity of this pathway are affected in Hacel $\mathrm{KO}$ mice. Recordings of field excitatory post synaptic potentials in response to CA3-CA1 synapse stimulation (schematic of the set-up in figure 4A) revealed an upregulation of excitatory synaptic transmission in hippocampal slices from Hace1 KO mice (figure 4, A and B). Further analysis showed that the increase in synaptic transmission at the CA3-CA1 synaptic pathway was most likely due to a postsynaptic effect of the $\mathrm{Hace} 1$ deletion because neither the axonal fiber volley (figure 4C) nor the paired-pulse ratio, an indirect measure of the presynaptic release probability, ${ }^{25}$ was affected (interstimulus interval $50 \mathrm{~ms}$, paired-pulse ratio: WT $1.70 \pm 0.066, \mathrm{n}=19$, Hace1 KO $1.66 \pm 0.036, \mathrm{n}=20, p=0.64$, 2-population $t$ test, not shown). We then probed long-term potentiation (LTP), a cellular correlate of memory formation, ${ }^{26}$ of this synaptic pathway and found that LTP is significantly reduced in acute hippocampal slices from Hacel $\mathrm{KO}$ mice compared with WT littermates (figure 4, D and E). Of note, nerve conduction velocity was not affected in Hacel $\mathrm{KO}$ recordings as compared with controls (data not shown), in line with the report that nerve conduction velocity is unaffected in SPPRS patients. ${ }^{6}$

Because we observed hippocampal-dependent contextual fear learning deficiency and dysfunctions in electrophysiologic properties of pyramidal cells within the CA1 region of the hippocampus, we analyzed morphological properties of pyramidal neurons in this brain region. To this end, we crossed Hace1 KO mice with Thyl-GFP-M mice to drive neuronal GFP expression, which allowed us to visualize neuronal morphology, including spines along dendrites of CA1 pyramidal cells. ${ }^{27}$ Quantification of selected dendritic segments indeed revealed a significant reduction in spine numbers in Hace1 KO neurons as compared with hippocampal neurons from WT littermates (figure 4F). Whether such reduction in the synapse number is also present throughout the brain and might explain defective locomotion in Hacel $\mathrm{KO}$ mice needs to be determined. These data indicate that, as a correlate to hippocampus-dependent impaired associate learning, HACE1 deficiency leads to a deficit of synaptic plasticity and a marked reduction of synapses in the hippocampus.

\section{Elevated levels of active Rac1 in Hace1 KO mouse brains and SPPRS \\ patient-derived fibroblasts}

To determine molecular alterations downstream of HACE1 deficiency, we focused on Ras-related C3 botulinum toxin substrate 1, RAC1, a well-characterized substrate for HACE1mediated proteasomal degradation. ${ }^{8,9}$ Indeed, Western blot analysis showed that RAC1 protein abundance was increased in Hace1 KO brains when compared with WT littermates (figure 5A). In addition, Cyclin D1 abundance and ROS levels, as downstream read-outs for RAC1 activity, ${ }^{12}$ were likewise increased in Hace1 $\mathrm{KO}$ brain regions as compared with controls (figure 5, A and B).

The role of RAC1 has been extensively studied in the context of mouse brain development. ${ }^{10,11}$ Of interest, perturbation of RAC1 levels, either overexpression or downregulation, results in decrease in dendritic spines in the mouse brain, similar to our Hace1 $\mathrm{KO}$ mice. ${ }^{10,28}$ To determine whether RAC1 is also changed in HACE1-mutant SPPRS patients, we performed Western blotting analysis of SPPRS patient-derived fibroblasts, isolated from patients 6,7 , and 10 (table). Of note, in these patients, the mutations result in undetectable HACE1 protein expression (figure 5C), resembling our Hacel $\mathrm{KO}$ mice. In all patients' fibroblasts, total abundance of RAC1 and Cyclin D1 was increased as compared with fibroblasts from HD controls (figure 5C). It is important that increased abundance of active GTP-bound RAC1 was detected in all 3 patient fibroblasts (figure 5D). As a functional consequence of increased RAC1 activity, ROS upregulation was also evident in SPPRS patient-derived fibroblasts (figure 5E). In addition, 
Figure 4 Altered long-term potentiation and reduced hippocampal synapse numbers in Hace1 KO mice as compared with WT controls
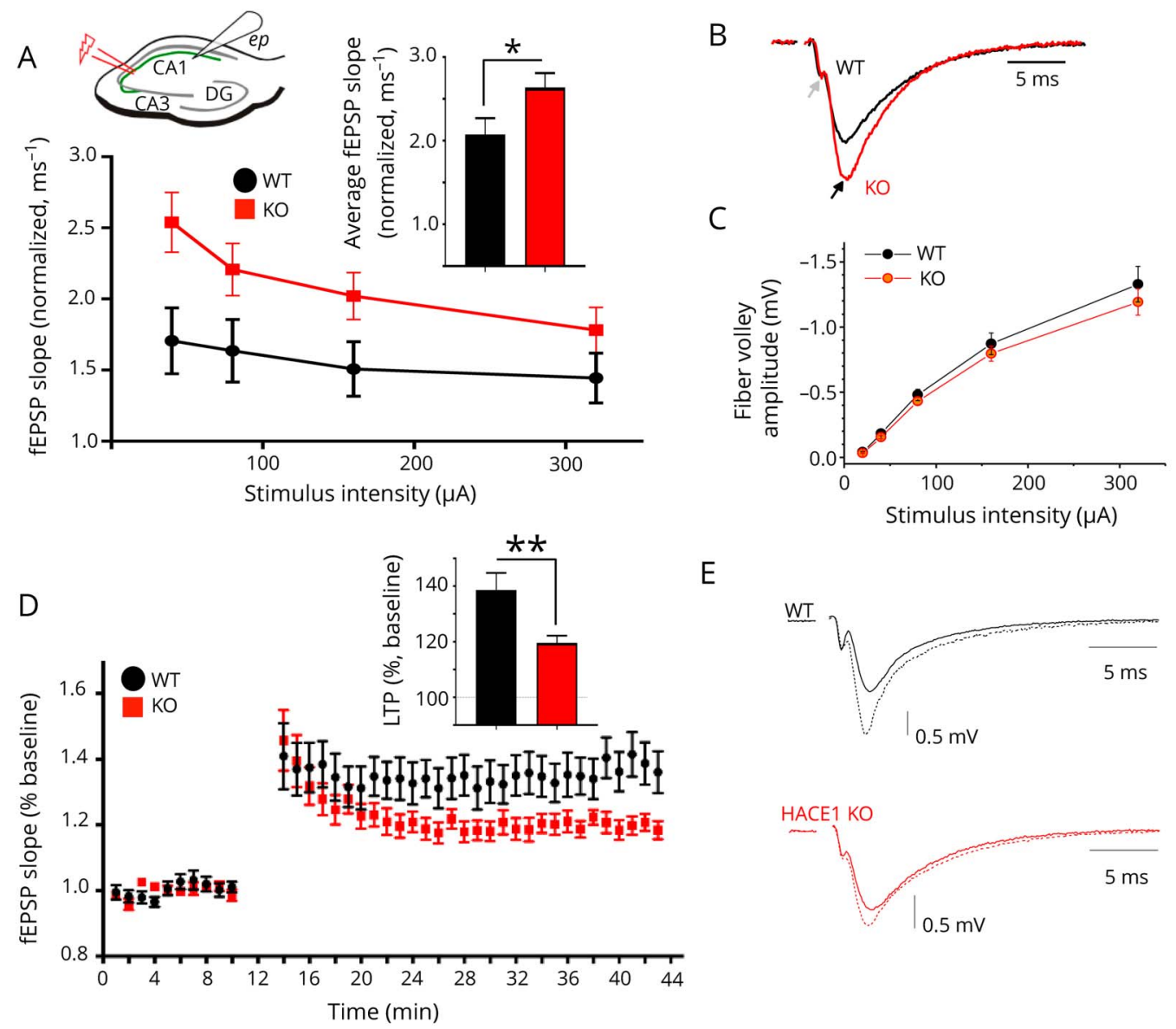

$E$
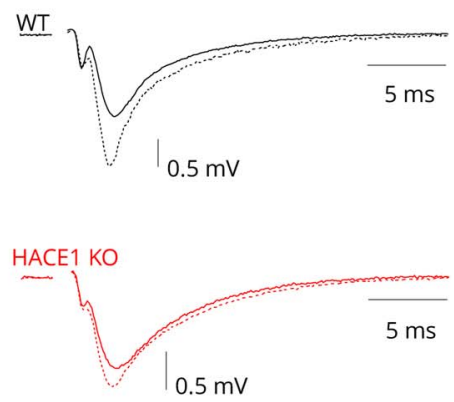

$\mathrm{F}$
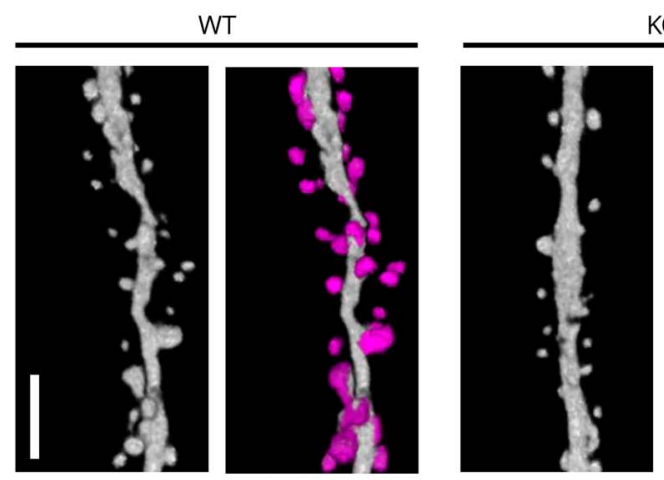

$\mathrm{KO}$
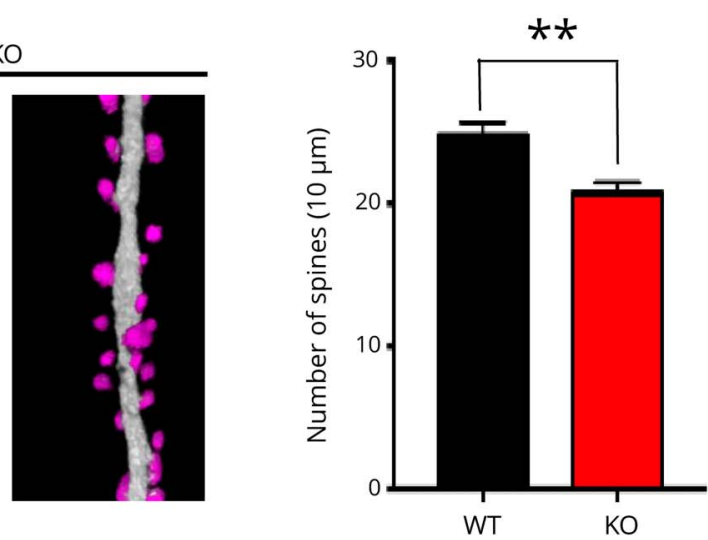

(A) Upper left panel, schematic fEPSP recording configuration from acute hippocampal slices: stimulation (red bolt) of CA3-CA1 Schaffer collaterals (green), the fEPSP extracellular recording electrode in the CA1 region (white cone, ep = extracellular pipette). Synaptic transmission at CA3-CA1 hippocampal synapses is increased in Hace 1 KO mice compared with WT littermates. fEPSP slopes were normalized to axonal fiber volleys to account for variations in axonal stimulation efficacy between slice preparations and animals. Analysis was performed over a range of stimulus intensities. Average fEPSP slopes were significantly higher in Hace 1 KO slices; mean values \pm SEM; WT $n=19$ and KO $n=20 ; * p \leq 0.05$; 2-population Student's $t$ test. (B) Representative traces of fEPSPs in response to CA3-CA1 synapse stimulation obtained from WT (black trace) and Hace1 KO (red trace) mice. Field EPSP (black arrow) recordings were normalized to fiber volleys (gray arrow) to account for varying stimulation efficiencies across experiments and preparations. Time scale of recording is indicated. (C) No significant difference was found between fiber volley amplitudes (mean values \pm SEM) between the indicated genotypes; WT $n=19$ and KO $n$ $=20$. (D) Long-term potentiation (LTP) of synaptic transmission was induced by HFS after a 10-minute baseline recording. fEPSP slopes were normalized to their baseline levels and plotted over time. LTP was reduced in Hace1 KO animals; mean values \pm SEM; WT $n=19$ and KO $n=18 ; * \star p \leq 0.01 ; 2$-population Student's $t$ test. (E) Representative fEPSP traces illustrating LTP experiments displayed in panel (D). Solid lines represent baseline fEPSPS, and dashed lines represent fEPSPS 30 minutes after LTP induction (Hace 1 WT: black, upper panel; Hace $1 \mathrm{KO}$ : red, lower panel). (F) Representative $3 \mathrm{D}$ composite of Z-stacked $\times 63$ magnified (zoom factor of 2) confocal images of hippocampal CA1 pyramidal cell distal dendrites of Hace $1^{+/+} ;$Thy 1-GFP and Hace $1^{-/-}$; Thy 1-GFP mice. Uncolored dendritic segments are on the left, synaptic spines are pseudocolored in magenta on the right panels; scale bar is $2.5 \mu$ m. Right bar graphs show quantifications of spine numbers; mean values $\pm \mathrm{SEM}$; WT $n=3$ and KO $n=3$; ** $p \leq 0.01$; unpaired Student's $t$ test. fEPSPs $=$ field excitatory post synaptic potentials; KO = knock out; WT = wild type. 
Figure 5 Hace 1 KO mouse brains and SPPRS patient-derived fibroblasts have elevated Rac1 and ROS levels

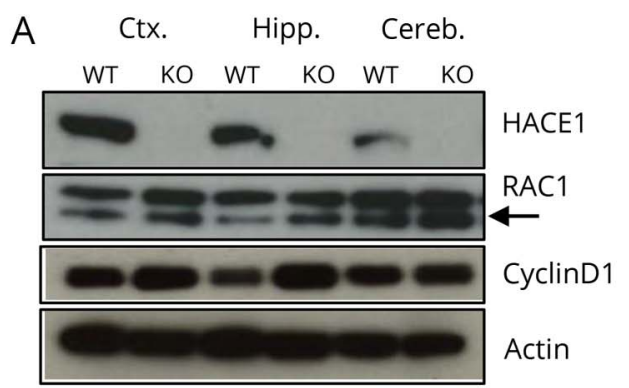

B

C

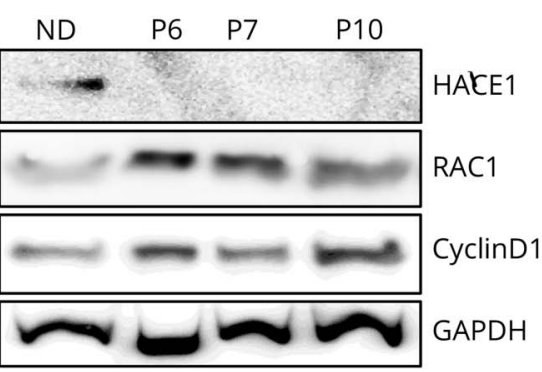

$\mathrm{E}$
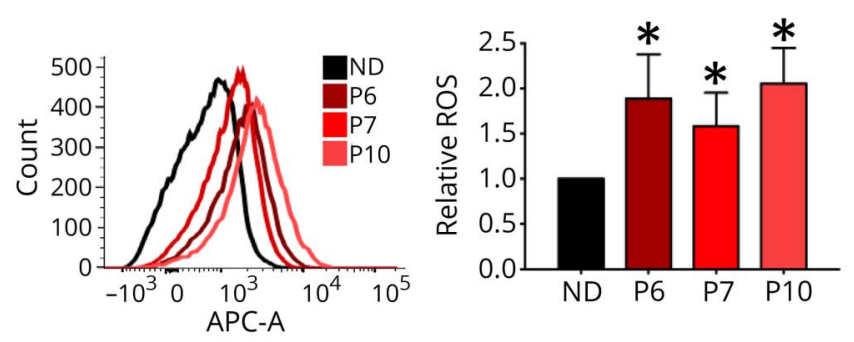

F. Scratch assay

G
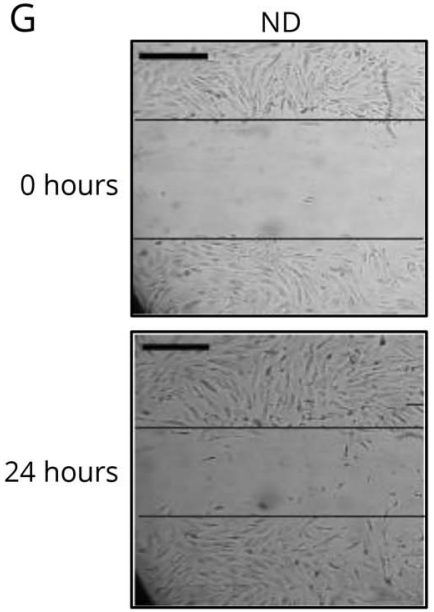
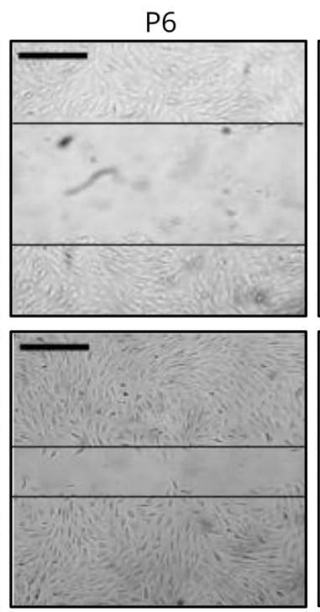

WT
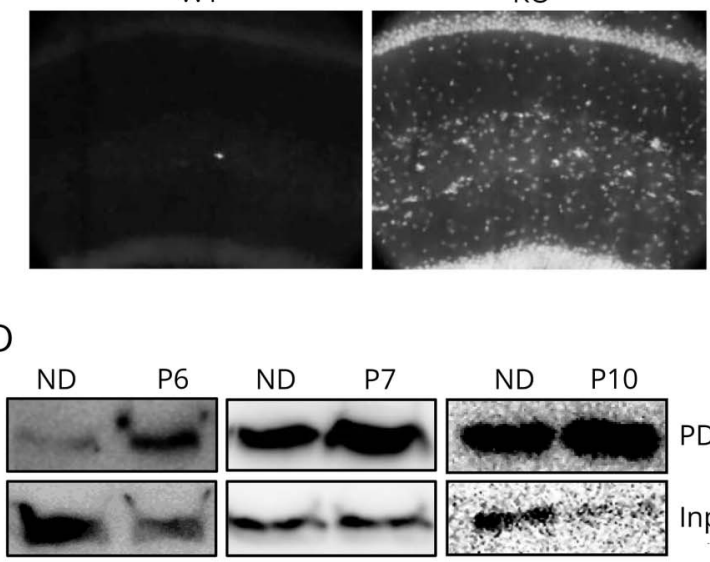

PD: act.RAC1

Input: RAC1

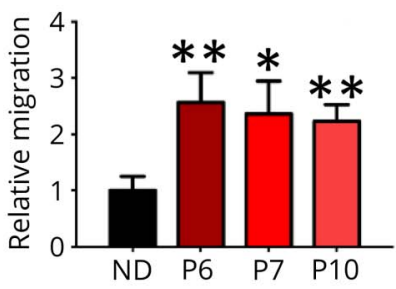

P7

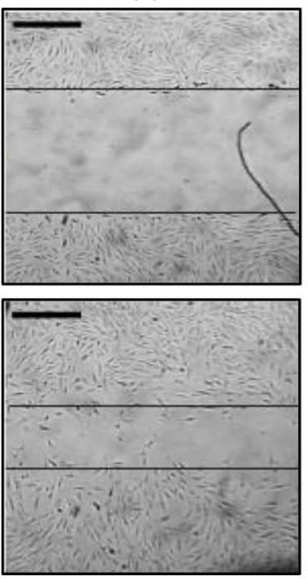

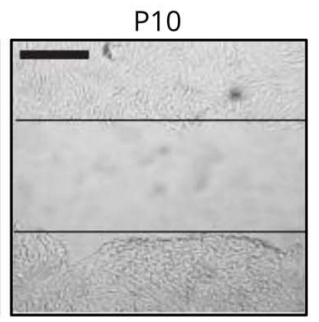

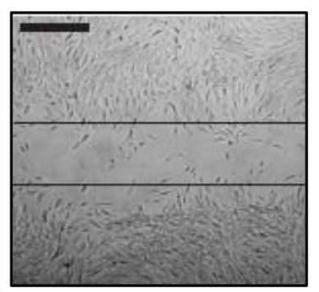

(A) Western blot analysis of the cortex (ctx.), hippocampus (hipp.) and cerebellum (cereb.) from WT and Hace1 KO mice revealed a strong upregulation of total RAC1 abundance (lower band, arrow) and Cyclin D1 protein in the absence of HACE1, in all indicated brain regions tested. Actin was used as a loading control. (B) ROS (detected by DHE staining) is elevated in the hippocampus of Hace $1 \mathrm{KO}$ mice as compared with WT littermates; $\times 20$ magnification. (C) Fibroblasts harvested from SPPRS patients (P6, P7, and P10) have no detectable HACE1 protein product as compared with normal donor fibroblasts (ND) as revealed by Western blotting using an antibody recognizing the HACE1 C-terminus; however, patient fibroblasts express elevated total abundance of RAC1 and Cyclin D1 protein product. GAPDH was used as a loading control. (D) SPPRS patient-derived fibroblasts exhibit elevated abundance of active RAC1 in comparison with normal donor fibroblasts, as measured by the Active RAC1 Pull-Down and Detection Kit. (E) Left panel, FACS analysis of SPPRS patient-derived fibroblasts incubated with CellROX deep red reagent revealed significantly more ROS in patient cells as compared with normal donor (ND) fibroblasts. Right panel, quantification of ROS production in the indicated patient and control fibroblasts; mean values \pm SD; $n=7$ for ND, P6, and P7 fibroblasts, and $n=3$ biological replicates for patient 10 fibroblasts; ${ }^{*} p \leq 0.05$; unpaired Student's $t$ test. (F and G) Confluent SPPRS patient P6, P7, P10 and ND-derived fibroblasts were subjected to scratch assays, and migration was monitored. Panel (F) shows a quantification of fibroblast migration rates; mean values $\pm \mathrm{SD} ; \mathrm{n}=3 ; * \star p \leq 0.01$ and $* * * p \leq 0.001$ comparing patient fibroblasts with the ND controls; unpaired Student's $t$ test. Representative images are shown in (G). KO = knock out; ROS = reactive oxygen species; SPPRS = spastic paraplegia and psychomotor retardation with or without seizures; WT = wild type.

in a scratch assay, patient fibroblasts migrated significantly faster, as compared with control fibroblasts (figure 5, $\mathrm{F}$ and $\mathrm{G})$, confirming enhanced RAC1 activity. ${ }^{29-32}$ These data show that loss of HACE1 expression results in increased levels of active RAC1 in both Hace1 KO mouse brains and HACE1mutant SPPRS patient-derived fibroblasts. 


\section{Discussion}

Here, we report 2 novel mutations in HACE1, p.Q209* and p.R332*, discovered in 3 patients from 2 unrelated consanguineous families with a complex neurodevelopmental disorder. These new patients have variable clinical symptoms, overlapping with previous descriptions of SPPRS. ${ }^{5-7}$ The genotype-phenotype correlations of the different mutations need to be addressed in future studies, as more SPPRS patients are diagnosed. We find that HACE1 is expressed throughout the adult mouse brain. Hacel $\mathrm{KO}$ mice have defects in basic sensorimotor processing, deficiencies in specific learning and memory tasks, reduced LTP of hippocampal CA3-CA1 synapses, and fewer synaptic spines at CA1 pyramidal neurons. In addition, they exhibit locomotion defects as compared with littermate controls. Furthermore, we show a marked upregulation of RAC1 levels throughout the mutant mouse brain and elevated ROS levels. Verifying that our findings are relevant in humans, active RAC1 abundance, downstream signaling components, ROS production, and cellular migration in SPPRS patientderived fibroblasts are likewise dysregulated, all indicative of a hyperactive RAC1 pathway. Thus, HACE1 deficiency leads to neuroradiologic and behavioral manifestations in mice reminiscent of the clinical features seen in SPPRS patients.

A well-characterized target for HACE1 ubiquitination and subsequent proteasomal degradation is $\mathrm{RACl}$, a small member of the Rho family of GTPases, critical for neurogenesis, migration, axonal elongation, synaptogenesis, and activitydriven plasticity. ${ }^{11} \mathrm{HACE} 1$ is therefore poised to regulate many functions of RAC1, by modulating its active GTP-bound levels, including NADPH-dependent ROS production. ${ }^{12,13}$

Mutations in several genes encoding guanine exchange factors and GTPase-activating proteins that regulate the on/off state of RAC1 have been identified to cause rare neuronal disorders. ${ }^{33,34}$ Indeed, analysis of a protein-protein interaction subnetwork extracted from the human-integrated proteinprotein interaction reference database ${ }^{35}$ reveals RAC1 to have 25 first-order interactors reported to be causative of intellectual disabilities. Neuronally expressed RAC1 first-order interactors are enriched in GTPase signal transduction by Gene Ontology analysis. Furthermore, RAC1 was also identified as a candidate gene for intellectual disability in a meta-analysis of several thousand trios, ${ }^{36}$ and RAC1 missense mutations were recently reported to cause a neurodevelopmental disorder with variable symptoms in 7 individuals, some of which are overlapping with SPPRS patients. ${ }^{37}$ Of interest, mutations in RAC1 caused remarkably different neurologic phenotypes that ranged from microcephaly to normal head circumference to macrocephaly, as well as variable intellectual disability (4/7), hypotonia (4/7), epilepsy (3/7), behavioral problems (3/7), and stereotypic movements $(2 / 7){ }^{37}$ The individuals who were determined to carry gain-of-function RAC1 mutations (3/7) had normal head circumference $(1 / 3)$ or megalocephaly $(2 / 3)$, in contrast to the
3 newly reported SPPRS patients here, who either had microcephaly $(1 / 3)$ or normal head circumference (2/3). Hypoplastic corpus callosum, hypotonia, intellectual disability, and hearing impairment were noted in some but not all patients carrying gain-of-function RAC1 mutations, requiring further examination of the specific or common molecular pathology of RAC1associated neurodevelopmental disorder and SPPRS.

Importantly, it has been previously established that dysregulation of RAC1 abundance in mouse models results in a decrease in dendritic spine number as well as reduction in hippocampal plasticity, as we have uncovered in our Hacel KO mice. ${ }^{10,28,38}$ We therefore speculate that RAC1 is a key factor underlining neuronal pathology in Hacel $\mathrm{KO}$ mice and HACE1-deficient patients. Whether RAC1-dependent cytoskeletal modulation and/or ROS homeostasis is the key determinant feature of HACE1-dependent neurodevelopmental deficiencies remains to be elucidated. The present study adds HACE1 to the large RAC1 regulatory complex, which when perturbed has deleterious consequence to brain development and neuronal function.

\section{Acknowledgment}

The authors thank patients and their families for their participation; members of the IMP Biooptics facility for their technical advice and assistance; Dr. David Keays, IMP, Vienna, for the use of behavioral equipment, and members of his team for helpful discussions. In addition, the authors thank Dr. Daniel Lin from Sunjin Lab for the technical support with 3D Images of dendritic spines. The work was supported by the Human Frontiers Science Program (HFSP, to C.H.), the German Research Foundation (DFG, SPP1757, SFB1089 to C.H.), FWF Lise Meitner Postdoctoral Fellowship to V.N., and EMBO Long-Term Fellowship to T.-P.P. F.J.K. is supported by the German Research Foundation (DFG) Research Unit 2488, 'ProtectMove'. J.M.P. is supported by The Austrian Academy of Sciences, the European Community's Seventh Framework Programme/Advanced ERC grant, and Era of Hope/DOD Excellence grant.

\section{Study funding}

No targeted funding reported.

\section{Disclosure}

V. Nagy has received government research funding from the Austrian Science Fund and the Lise Meitner Postdoctoral Fellowship; and has received foundation/society research support from the Ludwig Boltzmann Society. R. Hollstein, T.P. Pai, M.K. Herde, P. Buphamalai, and P. Moeseneder report no disclosures. E. Lenartowicz has received foundation/ society research support from the Ludwig Boltzmann Society. Anoop Kavirayani is employed with VBCFs, which receives government funding from the Austrian Federal Ministry of Education, Science, and Research and the City of Vienna. G. Christoph Korenke, I. Kozieradzki, R. Nitsch, A. Cicvaric, F.J. Monje Quiroga, M.A. Deardorff, E.C. Bedoukian, Y. Li, and G. Yigit report no disclosures. Jörg Menche has received 
government research support from the Vienna Science and Technology Fund. E. Ferda Perçin and B. Wollnik report no disclosures. Christian Henneberger has served on the editorial board for Frontiers in Molecular Neuroscience and Brain Research Bulletin; has received government research support from NRWRückkehrerprogramm; and has received foundation/society research support from the Human Frontiers Science Program. F.J. Kaiser has received government research support from the German Research Foundation. J.M. Penninger reports no disclosures. Go to Neurology.org/NG for full disclosures.

\section{Publication history}

Received by Neurology: Genetics July 19, 2018. Accepted in final form February 5, 2019.

\section{Appendix Authors}

\begin{tabular}{|c|c|c|c|}
\hline Name & Location & Role & Contribution \\
\hline $\begin{array}{l}\text { Vanja Nagy, } \\
\text { PhD }\end{array}$ & $\begin{array}{l}\text { IMBA, Institute of } \\
\text { Molecular } \\
\text { Biotechnology of the } \\
\text { Austrian Academy of } \\
\text { Sciences, VBC-Vienna } \\
\text { BioCenter Campus, } \\
\text { Austria and LBI-RUD, } \\
\text { Vienna, Austria }\end{array}$ & $\begin{array}{l}\text { First and co- } \\
\text { corresponding } \\
\text { author }\end{array}$ & $\begin{array}{l}\text { Conceptualized } \\
\text { and coordinated } \\
\text { the project. } \\
\text { Performed all } \\
\text { mouse behavioral } \\
\text { experiments, } \\
\text { analyzed the data, } \\
\text { and wrote the } \\
\text { manuscript. } \\
\text { Assisted with } \\
\text { manuscript editing. }\end{array}$ \\
\hline $\begin{array}{l}\text { Ronja } \\
\text { Hollstein, PhD }\end{array}$ & $\begin{array}{l}\text { University of Luebeck, } \\
\text { Germany }\end{array}$ & Author & $\begin{array}{l}\text { Performed all } \\
\text { experiments } \\
\text { pertaining to } \\
\text { human fibroblasts. } \\
\text { She assisted in } \\
\text { coordinating } \\
\text { clinical input and } \\
\text { assisted with data } \\
\text { analysis. Assisted } \\
\text { with manuscript } \\
\text { editing. }\end{array}$ \\
\hline $\begin{array}{l}\text { Tsung-Pin Pai, } \\
\text { PhD }\end{array}$ & $\begin{array}{l}\text { IMBA, Institute of } \\
\text { Molecular } \\
\text { Biotechnology of the } \\
\text { Austrian Academy of } \\
\text { Sciences, VBC-Vienna } \\
\text { BioCenter Campus, } \\
\text { Austria }\end{array}$ & Author & $\begin{array}{l}\text { Performed image } \\
\text { acquisition and } \\
\text { analysis of dendritic } \\
\text { spines. Assisted } \\
\text { with manuscript } \\
\text { editing. }\end{array}$ \\
\hline $\begin{array}{l}\text { Michel K. } \\
\text { Herde, PhD }\end{array}$ & $\begin{array}{l}\text { University of Bonn } \\
\text { Medical School, } \\
\text { Germany, and Centre } \\
\text { for } \\
\text { Neuroendocrinology, } \\
\text { Department of } \\
\text { Physiology, School of } \\
\text { Biomedical Sciences, } \\
\text { University of Otago, } \\
\text { Dunedin, New } \\
\text { Zealand }\end{array}$ & Author & $\begin{array}{l}\text { Designed, } \\
\text { performed, and } \\
\text { analyzed } \\
\text { electrophysiologic } \\
\text { experiments. } \\
\text { Assisted with } \\
\text { manuscript editing. }\end{array}$ \\
\hline $\begin{array}{l}\text { Pisanu } \\
\text { Buphamalai, } \\
\text { MSc }\end{array}$ & $\begin{array}{l}\text { CeMM, Vienna, } \\
\text { Austria }\end{array}$ & Author & $\begin{array}{l}\text { Performed and } \\
\text { analyzed the RAC1 } \\
\text { network analysis. } \\
\text { Assisted with } \\
\text { manuscript } \\
\text { editing. }\end{array}$ \\
\hline $\begin{array}{l}\text { Paul } \\
\text { Moeseneder, } \\
\text { MSc }\end{array}$ & $\begin{array}{l}\text { IMBA, Institute of } \\
\text { Molecular } \\
\text { Biotechnology of the } \\
\text { Austrian Academy of } \\
\text { Sciences, } \\
\text { VBC-Vienna } \\
\text { BioCenter Campus, } \\
\text { Austria }\end{array}$ & Author & $\begin{array}{l}\text { Assisted with } \\
\text { behavioral } \\
\text { experiments. } \\
\text { Assisted with } \\
\text { manuscript } \\
\text { editing. }\end{array}$ \\
\hline
\end{tabular}

Appendix (continued)

\begin{tabular}{|c|c|c|c|}
\hline Name & Location & Role & Contribution \\
\hline $\begin{array}{l}\text { Ewelina } \\
\text { Lenartowicz, } \\
\text { MSc }\end{array}$ & $\begin{array}{l}\text { LBI-RUD, Vienna, } \\
\text { Austria }\end{array}$ & Author & $\begin{array}{l}\text { Assisted with } \\
\text { behavioral } \\
\text { experiments. } \\
\text { Assisted with } \\
\text { manuscript } \\
\text { editing. }\end{array}$ \\
\hline
\end{tabular}

\begin{tabular}{|c|c|c|c|}
\hline $\begin{array}{l}\text { Anoop } \\
\text { Kavirayani, } \\
\text { DVM, Dip. } \\
\text { ACVP }\end{array}$ & $\begin{array}{l}\text { IMBA, Institute of } \\
\text { Molecular } \\
\text { Biotechnology of the } \\
\text { Austrian Academy of } \\
\text { Sciences, VBC-Vienna } \\
\text { BioCenter Campus, } \\
\text { Austria }\end{array}$ & Author & $\begin{array}{l}\text { Coordinated and } \\
\text { analyzed mouse } \\
\text { histologic findings. } \\
\text { Assisted with } \\
\text { manuscript editing }\end{array}$ \\
\hline
\end{tabular}

Georg C. Klinikum Oldenburg, Author Diagnosed and

Korenke, MD Oldenburg, Germany treated the

patients, obtained consents and/or biomaterials, and analyzed patient clinical data. Assisted with manuscript editing.

\begin{tabular}{|c|c|c|c|}
\hline $\begin{array}{l}\text { Ivona } \\
\text { Kozieradzki, } \\
\text { MSc }\end{array}$ & $\begin{array}{l}\text { IMBA, Institute of } \\
\text { Molecular } \\
\text { Biotechnology of the } \\
\text { Austrian Academy of } \\
\text { Sciences, VBC-Vienna } \\
\text { BioCenter Campus, } \\
\text { Austria }\end{array}$ & Author & $\begin{array}{l}\text { Assisted with } \\
\text { Western blotting. } \\
\text { Assisted with } \\
\text { manuscript } \\
\text { editing. }\end{array}$ \\
\hline
\end{tabular}

\begin{tabular}{|c|c|c|c|}
\hline $\begin{array}{l}\text { Roberto } \\
\text { Nitsch, PhD }\end{array}$ & $\begin{array}{l}\text { IMBA, Institute of } \\
\text { Molecular } \\
\text { Biotechnology of the } \\
\text { Austrian Academy of } \\
\text { Sciences, } \\
\text { VBC-Vienna } \\
\text { BioCenter Campus, } \\
\text { Austria, and }\end{array}$ & Author & $\begin{array}{l}\text { Assisted with early } \\
\text { conceptualization } \\
\text { of the project and } \\
\text { provided molecular } \\
\text { biology tools. } \\
\text { Assisted with } \\
\text { manuscript editing. }\end{array}$ \\
\hline
\end{tabular}

AstraZeneca,

Gothenburg, Sweden

Ana Cicvaric, Medical University of Author Designed,

PhD Vienna, Austria performed, and analyzed electrophysiologic experiments.

Assisted with manuscript editing.

\begin{tabular}{|c|c|c|c|}
\hline $\begin{array}{l}\text { Francisco J. } \\
\text { Monje }\end{array}$ & $\begin{array}{l}\text { Medical University of } \\
\text { Vienna, Austria }\end{array}$ & Author & $\begin{array}{l}\text { Designed, } \\
\text { performed, and }\end{array}$ \\
\hline
\end{tabular}

Quiroga, PhD $\quad$ analyzed electrophysiologic experiments. Assisted with manuscript editing.

\begin{tabular}{|c|c|c|c|}
\hline $\begin{array}{l}\text { Matthew A. } \\
\text { Deardorff, MD }\end{array}$ & $\begin{array}{l}\text { Univ. of Penn } \\
\text { Perelman School of } \\
\text { Med., and Children's } \\
\text { Hospital of } \\
\text { Philadelphia }\end{array}$ & Author & $\begin{array}{l}\text { Diagnosed and } \\
\text { treated the } \\
\text { patients, } \\
\text { obtained } \\
\text { consents and/or } \\
\text { biomaterials, and } \\
\text { analyzed patient } \\
\text { clinical data. } \\
\text { Assisted with } \\
\text { manuscript } \\
\text { editing. }\end{array}$ \\
\hline $\begin{array}{l}\text { Emma C. } \\
\text { Bedoukian, } \\
\text { MS }\end{array}$ & $\begin{array}{l}\text { Children's Hospital of } \\
\text { Philadelphia, PA }\end{array}$ & Author & $\begin{array}{l}\text { Diagnosed and } \\
\text { treated the } \\
\text { patients, obtained } \\
\text { consents and/or } \\
\text { biomaterials, and } \\
\text { analyzed patient } \\
\text { clinical data. } \\
\text { Assisted with } \\
\text { manuscript } \\
\text { editing. }\end{array}$ \\
\hline
\end{tabular}


Appendix (continued)

\begin{tabular}{|c|c|c|c|}
\hline Name & Location & Role & Contribution \\
\hline Yun Li, PhD & $\begin{array}{l}\text { University Medical } \\
\text { Center Göttingen, } \\
\text { Germany }\end{array}$ & Author & $\begin{array}{l}\text { Analyzed exome } \\
\text { data of family } 2, \\
\text { identified the } \\
\text { causative mutation, } \\
\text { and confirmed } \\
\text { cosegregation in the } \\
\text { family. Assisted with } \\
\text { manuscript editing. }\end{array}$ \\
\hline $\begin{array}{l}\text { Goekhan } \\
\text { Yigit, PhD }\end{array}$ & $\begin{array}{l}\text { University Medical } \\
\text { Center Goettingen, } \\
\text { Goettingen, Germany }\end{array}$ & Author & $\begin{array}{l}\text { Analyzed exome } \\
\text { data of family } 2, \\
\text { identified the } \\
\text { causative mutation, } \\
\text { and confirmed } \\
\text { cosegregation in the } \\
\text { family. Assisted with } \\
\text { manuscript editing. }\end{array}$ \\
\hline $\begin{array}{l}\text { Jörg Menche, } \\
\text { PhD }\end{array}$ & $\begin{array}{l}\text { CeMM, Vienna, } \\
\text { Austria }\end{array}$ & Author & $\begin{array}{l}\text { Performed and } \\
\text { analyzed the RAC1 } \\
\text { network analysis. } \\
\text { Assisted with } \\
\text { manuscript } \\
\text { editing. }\end{array}$ \\
\hline
\end{tabular}

\begin{tabular}{|c|c|c|}
\hline $\begin{array}{l}\text { E. Ferda } \\
\text { Percin, MD, }\end{array}$ & $\begin{array}{l}\text { Gazi University, } \\
\text { Ankara, Turkey }\end{array}$ & Author \\
\hline
\end{tabular}

PhD

Ankara, Turkey

patients, obtained

consents and/or

biomaterials, and analyzed patient

clinical data.

Assisted with

manuscript editing.

\begin{tabular}{lll}
\hline Bernd & University Medical & Author \\
Wollnik, MD & Center Goettingen, \\
& Goettingen, Germany
\end{tabular}

Analyzed exome data of family 2 , identified the causative mutation, and confirmed cosegregation in the family. Assisted with manuscript editing.

\begin{tabular}{|c|c|c|c|}
\hline $\begin{array}{l}\text { Christian } \\
\text { Henneberger, } \\
\text { MD }\end{array}$ & $\begin{array}{l}\text { University of Bonn } \\
\text { Medical School, Bonn, } \\
\text { Germany, and } \\
\text { University College } \\
\text { London, London, UK, } \\
\text { and German Center } \\
\text { for } \\
\text { Neurodegenerative } \\
\text { Diseases (DZNE), } \\
\text { Bonn, Germany }\end{array}$ & Author & $\begin{array}{l}\text { Designed, } \\
\text { performed, and } \\
\text { analyzed } \\
\text { electrophysiologic } \\
\text { experiments. } \\
\text { Assisted with } \\
\text { manuscript editing. }\end{array}$ \\
\hline $\begin{array}{l}\text { Frank J. } \\
\text { Kasier, PhD }\end{array}$ & $\begin{array}{l}\text { University of Luebeck, } \\
\text { Luebeck, Germany } \\
\text { DZHK e.V. (German } \\
\text { Center for } \\
\text { Cardiovascular } \\
\text { Research), Partner } \\
\text { Site Hamburg/Kiel/ } \\
\text { Lübeck, Lübeck, } \\
\text { Germany }\end{array}$ & Author & $\begin{array}{l}\text { Assisted with } \\
\text { project } \\
\text { coordination, } \\
\text { clinical } \\
\text { collaborations, data } \\
\text { analysis, and } \\
\text { writing the } \\
\text { manuscript. } \\
\text { Assisted with } \\
\text { manuscript editing. }\end{array}$ \\
\hline $\begin{array}{l}\text { Josef M. } \\
\text { Penninger, } \\
\text { MD }\end{array}$ & $\begin{array}{l}\text { IMBA, Vienna, Austria } \\
\text { Department of } \\
\text { Medical Genetics, Life } \\
\text { Science Institute, } \\
\text { University of British } \\
\text { Columbia, Vancouver, } \\
\text { Canada }\end{array}$ & $\begin{array}{l}\text { Co- } \\
\text { corresponding } \\
\text { author }\end{array}$ & $\begin{array}{l}\text { Conceived the } \\
\text { study and wrote } \\
\text { the manuscript } \\
\text { together with VN. } \\
\text { Assisted with } \\
\text { manuscript editing. }\end{array}$ \\
\hline
\end{tabular}

\section{References}

1. Anglesio MS, Evdokimova V, Melnyk N, et al. Differential expression of a novel ankyrin containing E3 ubiquitin-protein ligase, Hace1, in sporadic Wilms' tumor versus normal kidney. Hum Mol Genet 2004;13:2061-2074.

2. Zhang L, Anglesio MS, O'Sullivan M, et al. The E3 ligase HACE1 is a critical chromosome 6q21 tumor suppressor involved in multiple cancers. Nat Med 2007;13: $1060-1069$.
3. Diskin SJ, Capasso M, Schnepp RW, et al. Common variation at 6q16 within HACE and LIN28B influences susceptibility to neuroblastoma. Nat Genet 2012;44: $1126-1130$.

4. Tortola L, Nitsch R, Bertrand MJ, et al. The tumor suppressor Hacel is a critical regulator of TNFR1-mediated cell fate. Cell Rep 2016;15:1481-1492.

5. Akawi N, McRae J, Ansari M, et al. Discovery of four recessive developmental disorders using probabilistic genotype and phenotype matching among 4,125 families. Nat Genet 2015;47:1363-1369.

6. Hollstein R, Parry DA, Nalbach L, et al. HACE1 deficiency causes an autosomal recessive neurodevelopmental syndrome. J Med Genet 2015;52:797-803.

7. Hariharan N, Ravi S, Pradeep BE, et al. A novel loss-of-function mutation in HACE1 is linked to a genetic disorder in a patient from India. Hum Genome 2018;5:17061

8. Torrino S, Visvikis O, Doye A, et al. The E3 ubiquitin-ligase HACE1 catalyzes the ubiquitylation of active Rac1. Dev Cell 2011;21:959-965.

9. Castillo-Lluva S, Tan CT, Daugaard M, Sorensen PH, Malliri A. The tumour suppressor HACE1 controls cell migration by regulating Rac1 degradation. Oncogene 2013;32:1735-1742.

10. Luo L, Hensch TK, Ackerman L, Barbel S, Jan LY, Jan YN. Differential effects of the Rac GTPase on Purkinje cell axons and dendritic trunks and spines. Nature 1996;379:837-840.

11. Stankiewicz TR, Linseman DA. Rho family GTPases: key players in neuronal development, neuronal survival, and neurodegeneration. Front Cel Neurosci 2014;8:314

12. Daugaard M, Nitsch R, Razaghi B, et al. Hacel controls ROS generation of vertebrate Rac1-dependent NADPH oxidase complexes. Nat Commun 2013;4:2180.

13. Rotblat B, Southwell AL, Ehrnhoefer DE, et al. HACE1 reduces oxidative stress and mutant Huntington toxicity by promoting the NRF2 response. Proc Natl Acad Sci U S A 2014;111:3032-3037.

14. Iimura A, Yamazaki F, Suzuki T, Endo T, Nishida E, Kusakabe M. The E3 ubiquitin ligase Hace1 is required for early embryonic development in Xenopus laevis. BMC Dev Biol 2016;16:31.

15. Carola V, D’Olimpio F, Brunamonti E, Mangia F, Renzi P. Evaluation of the elevated plus-maze and open-field tests for the assessment of anxiety-related behaviour in inbred mice. Behav Brain Res 2002;134:49-57.

16. Deacon RM. Measuring motor coordination in mice. J Vis Exp 2013:e2609.

17. Metz GA, Whishaw IQ. The ladder rung walking task: a scoring system and its practical application. J Vis Exp 2009:1204.

18. Deacon RM, Rawlins JN. T-maze alternation in the rodent. Nat Protoc 2006;1:7-12.

19. Wehner JM, Radcliffe RA. Cued and contextual fear conditioning in mice. Curr Protoc Neurosci 2004, chapter 8:Unit 8.5C.

20. Vorhees CV, Williams MT. Assessing spatial learning and memory in rodents. ILARJ 2014;55:310-332.

21. Breuss MW, Hansen AH, Landler L, Keays DA. Brain-specific knockin of the pathogenic Tubb5 E401K allele causes defects in motor coordination and prepulse inhibition. Behav Brain Res 2017;323:47-55.

22. Minge D, Senkov O, Kaushik R, et al. Heparan sulfates support pyramidal cell excitability, synaptic plasticity, and context discrimination. Cereb Cortex 2017;27: 903-918.

23. Schneider CA, Rasband WS, Eliceiri KW. NIH Image to ImageJ: 25 years of image analysis. Nat Methods 2012;9:671-675.

24. Kochlamazashvili G, Henneberger C, Bukalo O, et al. The extracellular matrix molecule hyaluronic acid regulates hippocampal synaptic plasticity by modulating postsynaptic L-type $\mathrm{Ca}(2+)$ channels. Neuron 2010;67:116-128.

25. Regehr WG. Short-term presynaptic plasticity. Cold Spring Harb Perspect Biol 2012; 4:a005702.

26. Bliss TV, Gardner-Medwin AR. Long-lasting potentiation of synaptic transmission in the dentate area of the unanaesthetized rabbit following stimulation of the perforant path. J Physiol (lond) 1973;232:357-374.

27. Feng G, Mellor RH, Bernstein M, et al. Imaging neuronal subsets in transgenic mice expressing multiple spectral variants of GFP. Neuron 2000;28:41-51.

28. Bongmba OY, Martinez LA, Elhardt ME, Butler K, Tejada-Simon MV. Modulation of dendritic spines and synaptic function by Rac1: a possible link to Fragile $\mathrm{X}$ syndrome pathology. Brain Res 2011;1399:79-95

29. Nobes CD, Hall A. Rho GTPases control polarity, protrusion, and adhesion during cell movement. J Cel Biol 1999;144:1235-1244.

30. Kraynov VS, Chamberlain C, Bokoch GM, Schwartz MA, Slabaugh S, Hahn KM. Localized Rac activation dynamics visualized in living cells. Science 2000;290:333-337.

31. Liu S, Kapoor M, Leask A. Racl expression by fibroblasts is required for tissue repair in vivo. Am J Pathol 2009;174:1847-1856.

32. Kaverina I, Krylyshkina O, Small JV. Regulation of substrate adhesion dynamics during cell motility. Int J Biochem Cel Biol 2002;34:746-761

33. van Bokhoven $\mathrm{H}$. Genetic and epigenetic networks in intellectual disabilities. Annu Rev Genet 2011;45:81-104

34. Pengelly RJ, Greville-Heygate S, Schmidt S, et al. Mutations specific to the Rac-GEF domain of TRIO cause intellectual disability and microcephaly. J Med Genet 2016;53;735-742.

35. Alanis-Lobato G, Andrade-Navarro MA, Schaefer MH. HIPPIE v2.0: enhancing meaningfulness and reliability of protein-protein interaction networks. Nucleic Acids Res 2017;45:D408-D414.

36. Lelieveld SH, Reijnders MR, Pfundt R, et al. Meta-analysis of 2,104 trios provides support for 10 new genes for intellectual disability. Nat Neurosci 2016;19:1194-1196.

37. Reijnders MRF, Ansor NM, Kousi M, et al. RAC1 missense mutations in developmental disorders with diverse phenotypes. Am J Hum Genet 2017;101:466-477.

38. Zamboni V, Armentano M, Berto G, et al. Hyperactivity of Rac1-GTPase pathway impairs neuritogenesis of cortical neurons by altering actin dynamics. Sci Rep 2018;8: 7254. 


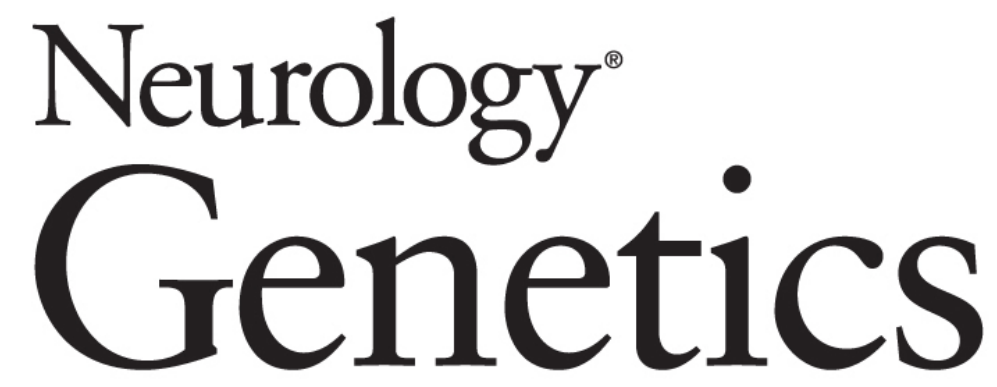

HACE1 deficiency leads to structural and functional neurodevelopmental defects Vanja Nagy, Ronja Hollstein, Tsung-Pin Pai, et al. Neurol Genet 2019;5;

DOI 10.1212/NXG.0000000000000330

This information is current as of April 30, 2019

Neurol Genet is an official journal of the American Academy of Neurology. Published since April 2015, it is an open-access, online-only, continuous publication journal. Copyright Copyright () 2019 The Author(s). Published by Wolters Kluwer Health, Inc. on behalf of the American Academy of Neurology.. All rights reserved. Online ISSN: 2376-7839.

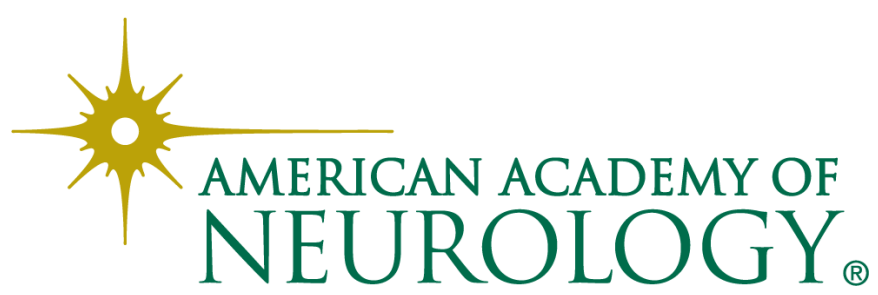




\section{Updated Information \& Services}

References

Citations

Subspecialty Collections

Permissions \& Licensing

Reprints including high resolution figures, can be found at: http://ng.neurology.org/content/5/3/e330.full.html

This article cites 36 articles, 6 of which you can access for free at: http://ng.neurology.org/content/5/3/e330.full.html\#\#ref-list-1

This article has been cited by 3 HighWire-hosted articles: http://ng.neurology.org/content/5/3/e330.full.html\#\#otherarticles

This article, along with others on similar topics, appears in the following collection(s):

\section{All Genetics}

http://ng.neurology.org//cgi/collection/all_genetics

Gait disorders/ataxia

http://ng.neurology.org//cgi/collection/gait_disorders_ataxia

Intelligence

http://ng.neurology.org//cgi/collection/intelligence

Mental retardation

http://ng.neurology.org//cgi/collection/mental_retardation

Spastic paraplegia

http://ng.neurology.org//cgi/collection/spastic_paraplegia

Information about reproducing this article in parts (figures,tables) or in its entirety can be found online at:

http://ng.neurology.org/misc/about.xhtml\#permissions

Information about ordering reprints can be found online:

http://ng.neurology.org/misc/addir.xhtml\#reprintsus

Neurol Genet is an official journal of the American Academy of Neurology. Published since April 2015, it is an open-access, online-only, continuous publication journal. Copyright Copyright $\odot 2019$ The Author(s). Published by Wolters Kluwer Health, Inc. on behalf of the American Academy of Neurology.. All rights reserved. Online ISSN: 2376-7839.

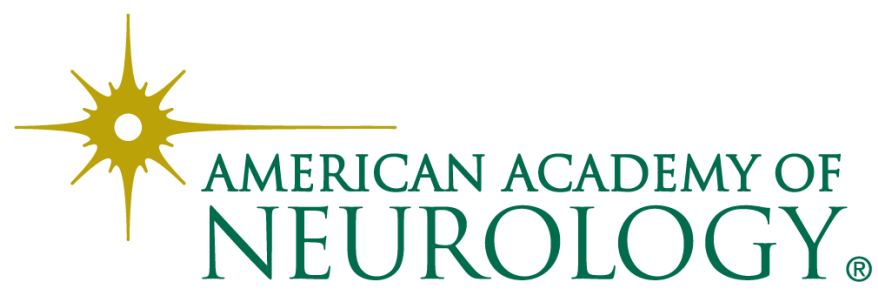

